\title{
Disruptive Technologies and Sustainable Supply Chain Management: A Review and Cross-Case Analysis
}

\author{
Khadija Ajmal $^{1}$, Nallan C. Suresh ${ }^{1} \&$ Charles X. Wang ${ }^{1}$ \\ ${ }^{1}$ School of Management, SUNY University at Buffalo, Buffalo, New York, USA \\ Correspondence: Khadija Ajmal, School of Management, Department of Operations Management \& Strategy, \\ University at Buffalo, The State University of New York, Buffalo, NY, 14260, USA. E-mail: kajmal@buffalo.edu
}

Received: May 10, 2021

Accepted: June 18, $2021 \quad$ Online Published: June 21, 2021

doi:10.5539/jms.v11n2p77

URL: https://doi.org/10.5539/jms.v11n2p77

\begin{abstract}
This study examines the relationship between disruptive technologies and their potential impacts on sustainable supply chain management (SSCM), with a focus on the following technologies: Big Data Analytics / Artificial Intelligence / Machine Learning, Blockchain, Industry 4.0 / Internet of Things (IoT), 3D Printing / Additive Manufacturing, and P2P / Sharing Economy. Based on a comprehensive literature review on both theoretical and practical roles of these disruptive technologies in SSCM, we conduct a cross-case study to analyze the impacts of disruptive technologies on sustainability performance. From 100 application cases of 41 companies in key supply chain management and sustainability journals, we develop a classification scheme based on implementation complexity and sustainability performance of disruptive technologies. The implementation complexity and sustainability performance matrix show that all the cases examined have a positive overall sustainability performance score which indicates that investment in disruptive technologies improves the sustainability performance of firms. However, the impact of each disruptive technology on sustainability performance varies with the types of technology and sustainability dimensions. We also utilize the cases to illustrate how disruptive technologies are applied to key areas of SSCM and identify opportunities for future research.
\end{abstract}

Keywords: cross-case study, disruptive technology, supply chain management, sustainability

\section{Introduction}

Technology plays a significant role in improving operational proficiency and enhancing supply chain performance (Bharadwaj et al., 2007). According to McKinsey (2013), disruptive technologies are expected to have an economic impact of $\$ 14$ trillion- $\$ 33$ trillion/year by 2025 by generating consumer surplus, lower prices, better health, and a cleaner environment. The concept of disruptive technology was initially introduced by Christensen (1997), who proposed that disruption occurs when an original inferior technology improves to such an extent that it starts to attract the mass market. Sood and Tellis (2013) further explain that disruption in technology takes place when a new technology has the potential to achieve better performance than the existing dominant technology. The role of technology, in this case, changes from just improving business models to changing the way business is conducted. For example, when ride-sharing platforms like Uber were introduced, they brought a huge change in the way people use and provide transport services.

While disruptive technology plays an integral role in supply chain management (SCM), understanding its impact on sustainability performance is also crucial. Sustainable supply chain management (SSCM) is a critical success factor for the sustainable growth of companies (Markley \& Davis, 2007; Rao \& Holt, 2005). SSCM offers benefits like waste generation reduction, retention of key employees, revenue maximization, and improved market share (Buyukozkan \& Berkol, 2011). Based on a systematic literature review of 188 papers from 2010 to 2016, Movahedipour et al. (2017) identify "inadequate information technology implementation" as the most significant barrier for business sustainability.

The objective of this research is threefold. First, this research aims to investigate the impacts of disruptive technologies on SSCM. Disruptive technologies like Blockchain, 3D Printing, Artificial Intelligence, Internet of Things, and others are "gathering force [and will] be far-reaching, affecting every corner of the factory and the supply chain" (McKinsey, 2015, p. 2). Considering all disruptive technologies under one study may make the scope of this research to be too broad. Hence this study focuses on major disruptive technologies like Big Data 
Analytics (BDA) / Machine Learning (ML) / Artificial Intelligence (AI), Blockchain, Industry 4.0 / Internet of Things (IoT), 3D Printing / Additive Manufacturing (AM), and P2P / Sharing Economy. Table 1 below provides definitions of the major disruptive technologies considered in this research. Second, since a wide range of disruptive technologies are being implemented in practice, this research examines how disruptive technologies are applied in the industry and how they impact various dimensions of sustainability performance. A cross-case study approach has been applied for this purpose. Third, we develop a classification matrix based on the implementation complexity and sustainability performance of disruptive technologies. It is conceivable that technologies with high sustainability performance may also be accompanied by complexities in implementation. Therefore, it is important to evaluate both sustainability impacts and implementation complexities of disruptive technologies.

The rest of this paper is organized as follows. In Section 2, we review the literature on disruptive technologies and SSCM. We then describe our research methodology in Section 3. Details of the cross-case analysis are presented in Section 4, and our assessment of sustainability impacts and implementation complexity are discussed in Section 5. We summarize our key research findings Section 6. Finally, we draw conclusions and identify opportunities for future research in Section 7.

Table 1. Definitions of disruptive technologies

\begin{tabular}{|c|c|c|}
\hline Technology & Definition & Sources \\
\hline $\begin{array}{l}\text { Machine Learning } \\
(\mathrm{ML})\end{array}$ & $\begin{array}{l}\text { Machine learning, a subset of Artificial Intelligence, is an application or } \\
\text { algorithm that learns and improves from experience without being explicitly } \\
\text { programmed. It is the capability of a machine to improve its own performance } \\
\text { using statistical models to make decisions and incorporating the result of each } \\
\text { new trial into that model }\end{array}$ & $\begin{array}{l}\text { Ali et al. (2015); Han et al. (2015); } \\
\text { Shafri (2017); Merriam Webster } \\
\text { (online); }\end{array}$ \\
\hline $\begin{array}{l}\text { Big Data Analytics } \\
\text { (BDA) }\end{array}$ & $\begin{array}{l}\text { An information asset that is characterized by high volume, velocity and variety } \\
\text { that requires specific technology and analytical methods for its transformation } \\
\text { into value. }\end{array}$ & $\begin{array}{l}\text { De Mauro et al. (2015); Anshari and } \\
\text { Alas (2015); Agarval and Dhar (2014); } \\
\text { Mišić and Perakis (2019); Etzion and } \\
\text { Aragon-Correa (2016); }\end{array}$ \\
\hline $\begin{array}{l}\text { Artificial } \\
\text { Intelligence (AI) }\end{array}$ & $\begin{array}{l}\text { AI can be described as a cluster of technologies and approaches that is statistical } \\
\text { and symbolic, and it aims at mimicking human cognitive functions or exhibiting } \\
\text { aspects of human intelligence by performing various tasks, mostly preceding } \\
\text { analytical, analytical mostly preceding intuitive, and intuitive mostly preceding } \\
\text { empathetic intelligence. }\end{array}$ & $\begin{array}{l}\text { Tredinnick (2018); Hoehndorf et al. } \\
\text { (2017); Jiang et al. (2017); Huang and } \\
\text { Rust (2018); Wirth (2018); }\end{array}$ \\
\hline Blockchain & $\begin{array}{l}\text { Blockchain is a digitized, decentralized, and public ledger of all digital events } \\
\text { that have been executed and shared among participating agents. These } \\
\text { transactions are documented in a chronological order, helping participants to } \\
\text { keep track without central record-keeping. Its four key characteristics are } \\
\text { decentralization, security, auditability, and smart execution. }\end{array}$ & $\begin{array}{l}\text { Ali et al. (2016); Han et al. (2013); Ji et } \\
\text { al. (2015); Crosby et al. (2016); } \\
\text { Steiner and Baker (2015); Saberi et al. } \\
\text { (2019); Tinianow (2018); Olsen and } \\
\text { Tomlin (2019); }\end{array}$ \\
\hline Industry 4.0 / IIoT & $\begin{array}{l}\text { Industry } 4.0 \text { or Industrial Internet of Things (IIoT) describes the integration of } \\
\text { Internet of Things (IoT) technologies into industrial value creation. It enables } \\
\text { real-time horizontal and vertical Internet-based connectedness of people, } \\
\text { machines, and objects, as well as information and communication technologies } \\
\text { for the dynamic management of complex business processes. }\end{array}$ & $\begin{array}{l}\text { Müller and Voigt (2018); Grischa et al. } \\
\text { (2018); Bauer et al. (2015); }\end{array}$ \\
\hline $\begin{array}{l}\text { 3D Printing / } \\
\text { Additive } \\
\text { Manufacturing }\end{array}$ & $\begin{array}{l}\text { Additive Manufacturing (AM), commonly known as 3D Printing is defined as } \\
\text { the process of producing objects from a 3D model by joining materials layer by } \\
\text { layer, directly from raw material in powder, liquid, sheet, or filament form } \\
\text { without the need for molds, tools, or dies enabling three dimensional objects to } \\
\text { be 'printed' on demand. }\end{array}$ & $\begin{array}{l}\text { ASTM (2010); Khajavi et al. (2014); } \\
\text { Holmström et al. (2010); Sasson and } \\
\text { Johnson (2015); Rogers et al. (2016); } \\
\text { Lipson and Kurman (2013); Bhandari } \\
\text { and Regina (2014); Kellens et al. } \\
\text { (2017); Petrovic et al. (2011); Olsen } \\
\text { and Tomlin (2019); }\end{array}$ \\
\hline $\begin{array}{l}\text { P2P / Sharing } \\
\text { Economy }\end{array}$ & $\begin{array}{l}\text { The sharing economy is defined as digitized platforms for peer-to-peer } \\
\text { exchanges. It involves a business model where consumers grant each other } \\
\text { temporary access to under-utilized physical assets, possibly for money or other } \\
\text { compensation. }\end{array}$ & $\begin{array}{l}\text { Meelen and Frenken (2015); Belk } \\
\text { (2014); Ferrell et al. (2017); Hamari et } \\
\text { al. (2016); Piscicelli et al. (2015); } \\
\text { Huber (2017); Botsman and Rogers } \\
\text { (2011); }\end{array}$ \\
\hline
\end{tabular}

\section{Literature Review}

We first review prior research on sustainability dimensions within the context of SSCM in section 2.1. Section 
2.2 provides a review of the positive and negative consequences of disruptive technologies for SSCM. In Section 2.3, we identify unaddressed or inadequately addressed issues in the literature.

\subsection{Sustainability Dimensions in SSCM}

Sustainability is frequently operationalized as having three pillars (i.e., economic, social, and environmental dimensions), which are also known as the "triple bottom line" (Elkington et al., 2007). Governments and companies also refer to sustainability as "sustainable development with 3Ps" (i.e., people, planet, and profit) where the profit may be substituted for prosperity (European Commission, 2002). The United Nation's "sustainable development goals" (SDGs) also cover these sustainability dimensions in areas like access to clean and inexpensive energy - Goal: 7, achieving acceptable work and economic progress-Goal: 8, innovating industry and infrastructure-Goal: 9, reduce inequalities - Goal: 10, develop sustainable communities and cities - Goal: 11, incur responsible production as well as consumption of products-Goal: 12, and environmental protection-Goals: 13 to 15 .

SSCM may be defined as the management of material, information, and capital flow as well as cooperation among companies along the supply chain while taking goals from the economic, environmental, and social dimensions of sustainable development into account to satisfy customer and stakeholder requirements (Seuring et al., 2008). SSCM can result in significant benefits like increased market share, reduced waste generation, better employee retention, and revenue maximization (Buyukozkan \& Berkol, 2011). SSCM is also a critical success factor for the sustainable development of companies (Markley \& Davis, 2007; Rao \& Holt, 2005).

However, Linton et al. (2007) point out that the convergence of sustainability and SCM involves myriad issues that transcend the core of SCM. They identify areas such as product design, manufacturing by-products, by-products produced during product use, product life extension, product end-of-life, and recovery processes at end-of-life as being essential components for SSCM. In a similar vein, Guide and Wassenhove (2009) define a closed-loop SCM as "the design, control, and operation of a system to maximize value creation over the entire life cycle of a product with the dynamic recovery of value from different types and volumes of returns over time". Efficiently managing just one end of the supply chain like product returns can have a huge economic impact. Stock et al. (2002) estimate that commercial returns can cost over $\$ 100$ billion annually. Larger retailers can have product return rates of about $10 \%$ or higher of their net sales that can amount to millions of dollars per retailer.

Dubey et al. (2015) provide a comprehensive list of sustainability dimensions under the context of sustainable manufacturing. Figure 1 below summarizes the three sustainability dimensions applicable to this research. The three main pillars of sustainability, namely, economic, social, and environmental dimensions, are affected by an array of supply chain initiatives ranging from procurement, product design, manufacturing and distribution, and reverse logistics, to form a closed-loop SCM environment.

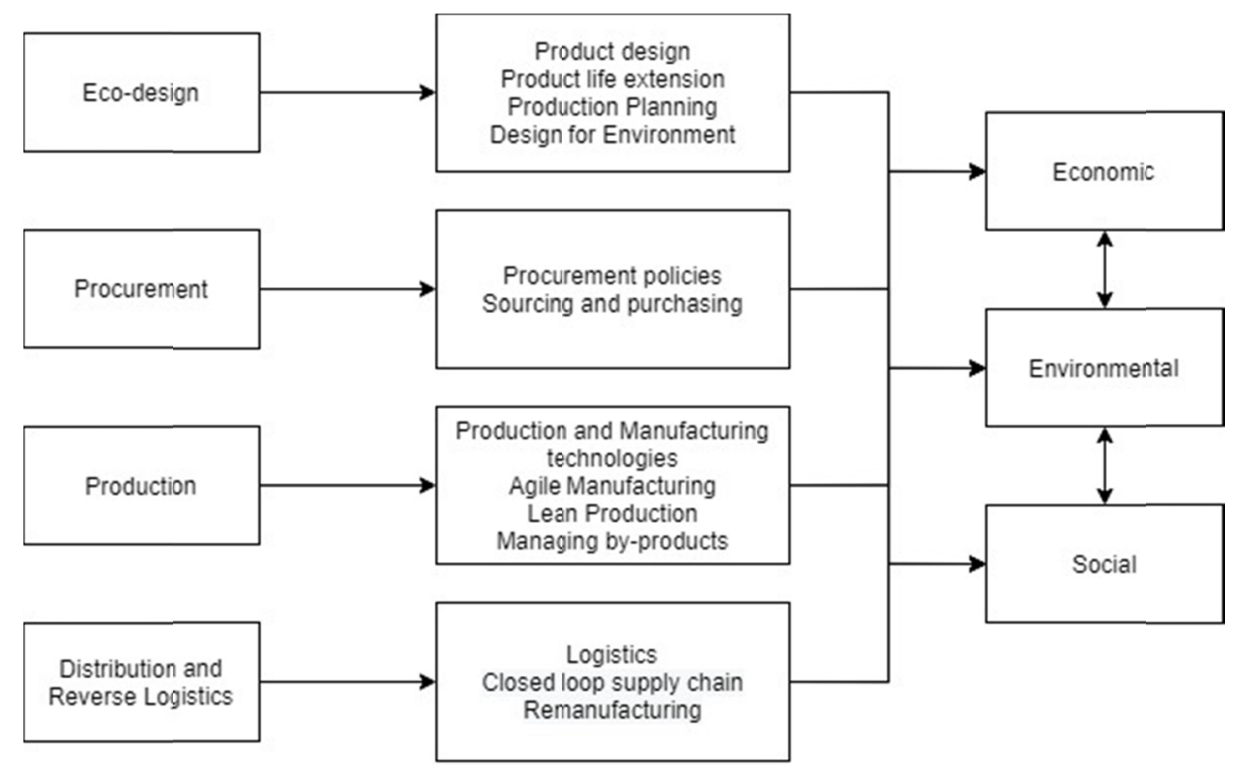

Figure 1. Framework of sustainability dimensions 


\subsection{Disruptive Technologies}

Dolgui and Ivanov (2020) discuss positive and negative "triggers" of supply chain structural dynamics. Examples of positive triggers include Blockchain, Industry 4.0, Sharing Economy, and Sustainability. They claim that adoptions of these disruptive technologies provide a competitive advantage to firms. Sweeny et al. (2020) conduct a survey focusing on global supply chain functions and find a significant correlation between firm performance and digital technology adoption. A systematic literature review on two disruptive technologies on SCM has been provided by Aryal et al. (2018). The authors make the case that data is a key driver for disruptive technology. In this subsection, we provide a literature review on disruptive technologies with a focus on their applications in SSCM.

\subsubsection{Big Data Analytics (BDA) / Machine Learning (ML) / Artificial Intelligence (AI)}

The disruptive technologies of BDA, ML, and AI are highly interrelated. ML can be considered a subset of AI, and both ML and AI can be considered part of BDA (Marr, 2017). Benjaafar and Hu (2019) provide a comprehensive review of BDA research and stipulate that machines using AI capabilities will substitute humans for many activities in the future. They call for research investigating the implications of large-scale smart machines. For instance, driverless cars will likely replace human drivers for ride-hailing services in the near future. Olsen and Tomlin (2019) expect AI to have a substantial effect on many supply chain processes. For example, in the agricultural field, facial recognition will allow farmers with large herds to get just as much knowledge about individual cows as farmers with small herds to improve milk yield (Koeleman, 2016).

Digital data volumes are also growing exponentially, and were projected to reach 35 Zeta bytes by 2020 (Tien, 2012). BDA is not only closely associated with the field of SCM but is considered as "one of the most prominent recent developments in the field" (Choi et al., 2018). There is a large body of research that has highlighted the benefits of BDA in operations, decision-making, and firm performance in various industries (Wang et al., 2016; Hofmann, 2015; Wamba \& Akter, 2015; Tan et al., 2015; Zhong et al., 2016). For instance, a McKinsey report states that profit margins of retailers can increase by more than $60 \%$ if BDA is exploited fully (Manyika et al., 2011). A heuristic tool using greedy construction links both fixed-effects and random forest models together and shows revenue increase by up to $36 \%$ (Mišić \& Perakis, 2019).

For sustainability, data-based enterprise systems like ERP can support accurate and continuous accounts of carbon emissions. This can lead to significant benefits like simple and accurate data collection and consistency of results (Zvezdov \& Hack, 2016). Similarly, enterprise systems play a pivotal role in smart cities and contribute to the three pillars of sustainability on top of traditional performance indicators (Ahmad \& Mehmood, 2015). Verma and Singh (2017) show that using intelligent retail mining tools with BDA can reduce the spoilage of products for retailers.

However, some shortcomings of BDA have also been recognized. Total losses resulting from identity theft were \$15.4 billion in 2014 (Harrell, 2017). BDA may also lead to biased results. Cohen (2018) reports issues with insurance companies where BDA results came out biased towards minority neighborhoods. These neighborhoods were given higher premiums for car insurance compared to other areas with the same risk level. Similarly, a non-profit firm used ML and other BDA techniques to collect news stories involving hate crimes and incidents of bias. It finds evidence showing machine bias against a certain race (Propublica, 2016). Also, Gartner (2007) claims that "information and communication technology (ICT) accounted for about $2 \%$ of global $\mathrm{CO}_{2}$ emissions in 2007, and this amount was comparable to the emissions associated with aviation". Corbett (2018) suggests that even though some of the biggest data centers rely more on renewable energy, they still incur significant costs like land and material use, noise pollution, and more. A challenging front is that a significant amount of data, collected at a high cost, are not utilized. For instance, an estimate by IBM stipulates that about $90 \%$ of stored data, never gets used (Johnson, 2015).

\subsubsection{Blockchain}

Blockchain improves key SCM objectives such as cost, flexibility, dependability, quality, speed, sustainability, and risk reduction (Kshetri, 2018). Its applications are rapidly disrupting supply chains (Lohade, 2017), payment systems (Nakamoto, 2008), healthcare (Plant, 2017; Ekblaw et al., 2016), and sustainability (Kouhizadeh \& Sarkis, 2018; Saberi et al., 2019). Blockchain can also improve transparency and accountability in supply chain activities and make sustainability indicators more measurable and meaningful (Kshetri, 2018). Blockchain also has the potential to reduce opportunistic behavior in supply chains (Saberi et al., 2018). A comprehensive review on Blockchain by Babich and Hilary (2019) concludes that Blockchain has five key strengths in SCM: aggregation, resiliency, validation, visibility, and automation. 
However, Blockchain can have adverse effects like higher overhead costs as it involves validation and replication, higher setup costs, and high transaction costs based on the consensus mechanism used (Kumar et al., 2019). Of the 26,000 Blockchain projects initiated in 2016, only 8\% were still active in 2017 (Browne, 2017). Blockchain-based bitcoin mining consumes high energy levels and thus increases greenhouse gas emissions (Truby, 2018). Babich and Hilary (2019) summarize five pitfalls of Blockchain: (1) "garbage in, garbage out" (GIGO) problem, (2) lack of privacy, (3) inefficiency, (4) lack of standardization, and (5) the black-box effect. Kumar et al. (2019) also suggest that Blockchain "is not a silver bullet for all applications. It incurs a very high overhead in terms of storage, networking, and processing costs that can be justified only after a thorough case-by-case analysis".

\subsubsection{Industry 4.0 / IoT}

Facts and Factors Report (2020) estimated the global Industry 4.0 market at $\$ 70$ billion in 2019 and expects it to reach $\$ 260$ billion by 2026. Similarly, McKinsey (2015) estimates that the economic impact of IoT will reach trillions of dollars by 2025. SCM application areas such as inventory management, optimization opportunities, worker productivity, and maintenance will account for a major portion of this impact. In the agricultural industry, deployed sensors lead to a precise application of insecticides and water levels by taking local conditions into account. Olsen and Tomlin (2019) state that Industry 4.0 technologies in isolation or as a combination can improve one or more priorities like cost, quality, speed, and flexibility and hence reduce the natural tension between these priorities.

However, the benefits of Industry 4.0 may be offset by technical challenges of ensuring security and privacy, lack of standardization (Xu et al., 2018), or societal and scientific issues (Zhou et al., 2015). Since Industry 4.0 is still in its infancy, more efforts are needed to tackle these challenges.

\subsubsection{P2P / Sharing Economy}

P2P / Sharing Economy platforms have had a significant economic impact. Chen et al. (2019) find that in 2018, of the ten highest-valued venture-backed firms listed in the Wall Street Journal, seven of those were online platforms. Furthermore, for crowdsourcing, another type of P2P technology, it is reported that " $85 \%$ of the top global brands have used crowdsourcing in the last ten years; and by $2018,75 \%$ of the world's high performing enterprises will be using crowdsourcing" (Yannig, 2016).

Benjaafar and $\mathrm{Hu}$ (2019) examine the interface between P2P/Sharing Economy and traditional SCM areas. They note that Sharing Economy can, on the one hand, increase access and, on the other hand, reduce the number of resources needed to gain access. For sustainability, P2P can enhance consumer welfare by allowing access to assets/services that they could otherwise not afford. It is also an income source for the owners. P2P can also reduce societal costs by reducing pollution generated throughout the product/service lifecycle. For instance, ride-sharing services provided by Uber can decrease the carbon-dioxide emission levels (Arnold \& Hildebrandt, 2017). Online shopping portals like Etsy can further generate jobs for women with low incomes (House of Lords, 2016). P2P platforms using dynamic pricing and wage models can benefit both workers and consumers compared to fixed pricing and wage models (Cachon et al., 2017).

However, there can be some undesirable consequences attributed to P2P / Sharing Economy. For instance, Burtch et al. (2018) find that entrepreneurial activity has decreased in the U.S. cities when Uber entered those markets. Benjaafar et al. (2017) conclude that ride-sharing platforms that prefer fewer seat occupations for revenue-maximization create high levels of traffic congestion. Increased sharing could increase the ownership of assets and products that are too expensive before as they become affordable due to rental income (Benjaafar \& $\mathrm{Hu}, 2019)$.

\subsubsection{D Printing / Additive Manufacturing (AM)}

3D Printing / AM can reduce production and inventory-related costs by designing products with considerably fewer parts. For instance, General Electric made an engine through AM using only a dozen components instead of previously 855 parts (Olsen \& Tomlin, 2019). The authors also suggest that AM is beneficial from the sustainability perspective as the amount of material that gets wasted in the production process is considerably lower. Similarly, a company used AM to design and manufacture a new tip of its aircraft engine's fuel nozzle that had an impossibly complex interior geometry. Now the company can manufacture about 30,000 nozzles per year (Orcutt, 2016). Considering the product life-cycle approach for aircraft components, Huang et al. (2016) expect substantial savings resulting from the lower weight of components manufactured through AM. Furthermore, through 3D Printing, it is possible to locate the AM equipment closer to assets. This will allow immediate on-demand printing of service parts and drastically reduce inventory levels. Siemens has launched such an 
initiative where spare parts for large gas turbines will be printed on-demand (Anner, 2016).

\subsection{Unaddressed Issues in the Literature}

Although there is a fast-growing body of research on disruptive technologies, there are still many unaddressed, or inadequately addressed issues regarding their applications in SSCM. For instance, Babich and Hilary (2019) review the potential of Blockchain and its possible downsides and recommend future research areas applicable to SSCM. They stipulate that Blockchain can help trace product roots at the manufacturing end and aggregate data at the product disposal end. Blockchain has the potential to provide a low-cost platform to all companies involved in the product's journey, such as suppliers, manufacturers, recyclers, regulators, and landfill operators, to share and validate product information. They recommend that an important research question to ponder is to identify applications that have earned high trust in their capabilities and provide a taxonomy of those applications. Kumar et al. (2019) discuss some technical challenges for Blockchain and identify future research opportunities. They posit that amount of trust in the supply chain is a major determinant in deciding if Blockchain is an appropriate investment. In cases where parties have low trust levels, Blockchain can provide supply chain visibility more efficiently and effectively. Kouhizadeh and Sarkis (2018) compile the practical uses of Blockchain for companies to achieve SSCM initiatives. Similarly, Kshetri (2018) analyzes the impact of Blockchain on sustainability objectives in the supply chains. Saberi et al. (2019) discuss the economic, environmental, social, and governance mechanisms where Blockchain can support sustainability goals.

Choi et al. (2018) review the BDA literature and explore existing techniques, functionalities, and major strengths and weaknesses of BDA in key SCM topics like inventory management, risk analysis, marketing, forecasting, and transportation management. They identify two studies on the application of BDA in SSCM. Specifically, Kaur and Singh (2018) develop a BDA model to address the environmental sustainability issues in procurement and logistics. Another study by Badiezadeh et al. (2018) uses the BDA approach to assess supply chain systems via sustainability scores. Corbett (2018) also provides a review of the sustainability challenges attributed to the use of BDA. Guha and Kumar (2018) discuss BDA applications and challenges in domains like IoT, AM, smart healthcare, cloud computing, and smart cities. Kumar et al. (2018) explore the research interface between operations management (OM) and information systems and discuss areas like ML, AI, Industry 4.0, Blockchain, smart cities, online platforms, and healthcare management.

Benjaafar and $\mathrm{Hu}$ (2019) examine the convergence of the classical OM theories and P2P/Sharing Economy. They discuss P2P resource sharing and on-demand service and rental platforms within the OM context. Chen et al. (2019) classify online platforms into five types based on their respective business models and highlight both strategic and operational considerations for each platform. Olsen and Tomlin (2019) integrate OM with Industry 4.0 technologies and stipulate that natural tensions between OM objectives can lessen due to these technologies. Long et al. (2017) explore the impact of AM on Chinese manufacturing and how some developmental issues can be alleviated through this technology.

More broadly, we identify two major gaps in the literature. First, past research, for the most part, has primarily dwelt on the economic impact of disruptive technologies in supply chains. Very few studies have investigated the impacts of disruptive technologies on all three dimensions of sustainability in supply chains. Second, to the best of our knowledge, there is no prior research that has examined all the above mentioned disruptive technologies collectively within the context of SSCM. These are important gaps in the literature that we attempt to fill through this cross-case study.

\section{Research Methodology}

In order to relate theory with practice, we conducted a comprehensive search for application cases of disruptive technologies in SSCM. We used the keywords of sustainability, sustainable, green, environment, social responsibility, corporate social responsibility (CSR), or performance combined with each disruptive technology defined in Table 1 to search two databases: Business Source Complete and Web of Science. This process yielded a total of 100 relevant, and usable articles in our sample. The publication dates of these articles ranged from 2010-2019 with over $85 \%$ of articles published in 2018 and 2019. The breakdown of these articles concerning disruptive technologies is presented in Figure 2. In the few instances when an article discussed more than one disruptive technology, the technology which was the main focus of the study was used as a classifier. Since the process of identifying the focal topic of an article is straightforward, with little ambiguity, and with no restrictions placed on the journals, selection bias was not deemed to be a cause for concern in this investigation. 


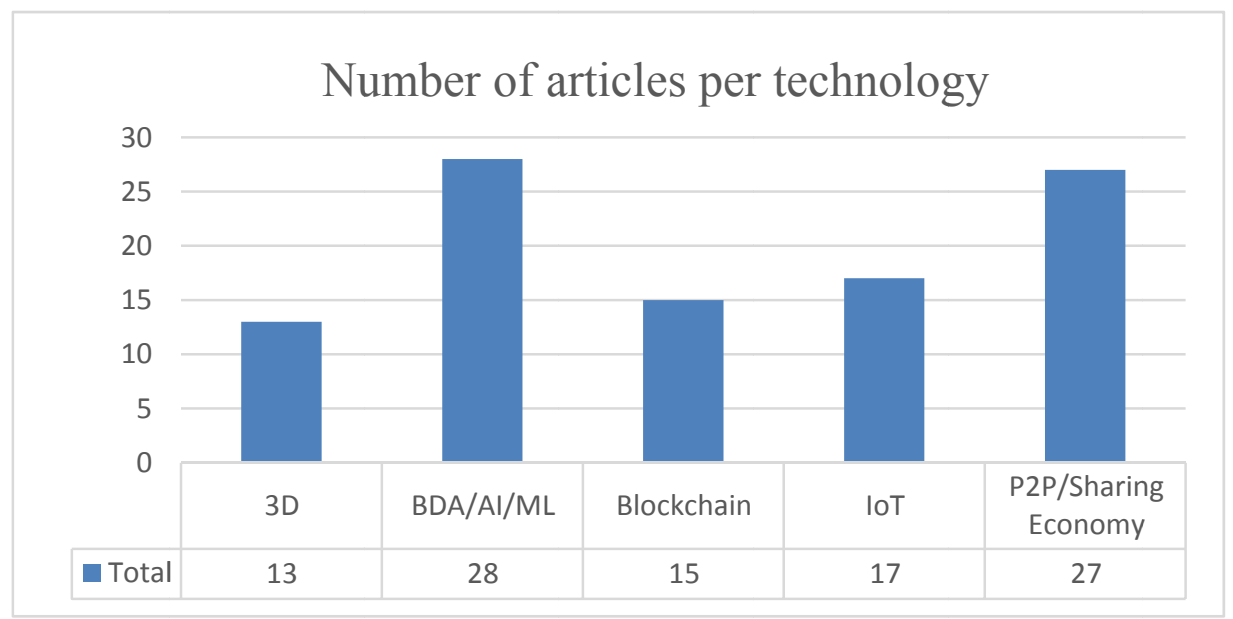

Figure 2. Breakdown of articles with respect to disruptive technologies

The majority of the articles came from journals devoted to sustainability (22 from Sustainability and 16 from Journal of Cleaner Production). Another portion of the sample came from OM journals (5 from Production and Operations Management, 5 from Manufacturing \& Service Operations Management, and 4 from International Journal of Production Research). All other journals had 3 or fewer articles where the vast majority of the journals contributed only one article in our sample. Hence, a diverse pool of journals from varying fields have been incorporated into this research.

We next carefully reviewed the 100 articles and recorded all cases related to the application of disruptive technologies from each article. A total of 41 cases were identified using this approach. They were then classified under the company name so that all cases of the same company were pooled together into one column. The next step was to classify each case under the three sustainability dimensions and then into a category of positive or negative consequence in that sustainability dimension. Lastly, a cross-case analysis approach was applied for theory-building purposes. Figure 3 below summarizes the process:

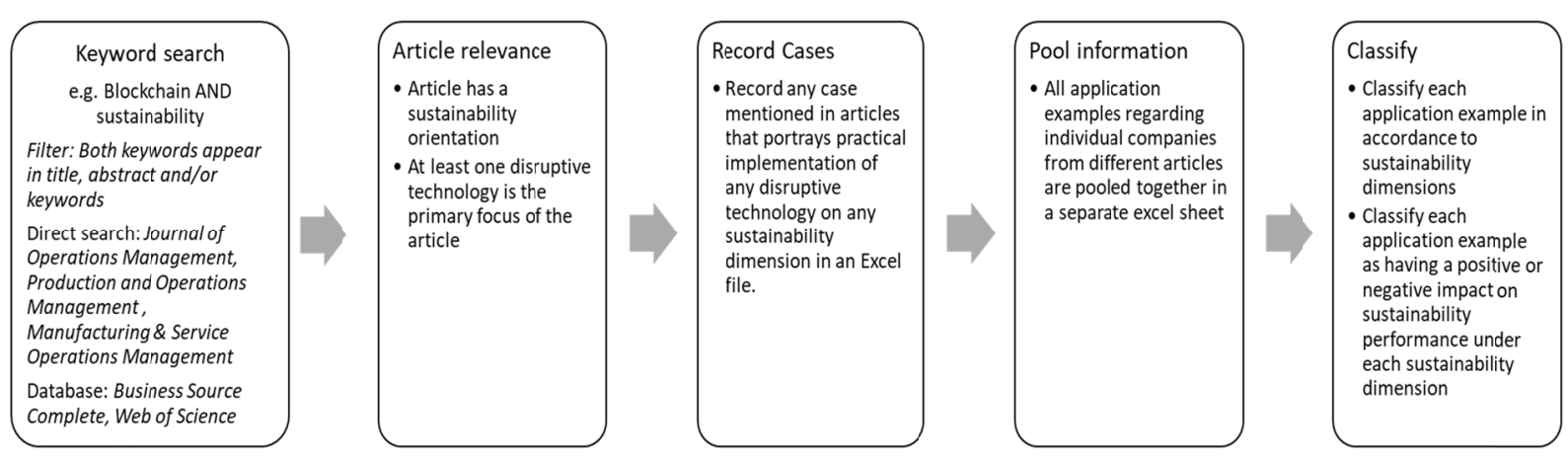

Figure 3. Research methodology

\section{Cross-Case Analysis}

In this section, we analyze real-world application cases of disruptive technologies and their possible impacts on the sustainability performance of supply chains. The aim is to understand the positive and negative consequences of each disruptive technology under dimensions of sustainability. An iterative triangulation process (Lewis, 1998) is used to conduct the cross-case analysis. Companies using disruptive technologies and their assigned case numbers are provided in Table 2. Furthermore, a summary of the case analysis and respective case numbers is presented in Table 3. 
Table 2. Company names and case numbers

\begin{tabular}{llllll}
\hline Company Name & Case \# & Company Name & Case \# & Company Name & Case \# \\
\hline Airbnb & 1 & Facebook & 16 & Recupe.net & 31 \\
Airbus & 2 & Fieldready.org & 17 & Rolls Royce & 32 \\
Amazon & 3 & Filabot & 18 & Siemens & 33 \\
Apple & 4 & FLEXE & 19 & Singapore Live! & 34 \\
BlaBla Car & 5 & General Electric & 20 & Too Good To Go & 35 \\
Boeing & 6 & General Motors & 21 & Uber & 36 \\
Car2Go & 7 & Google & 22 & Veridium Laboratories & 37 \\
Carrefour & 8 & IBM & 23 & Walmart & 38 \\
Caterpillar & 9 & iFixit & 24 & Walt Disney & 39 \\
Couchsurfing & 10 & Ikea & 25 & Winsun New Materials & 40 \\
Deloitte & 11 & Kobe & 26 & Yedioth Group & 41 \\
Energo & 12 & Maersk & 27 & & \\
Equifax & 13 & Peerby & 28 & & \\
EVCARD \& Mobike & 14 & Provenance & 29 & & \\
Everledger & 15 & RBS Assetz Capital & 30 & & \\
\hline
\end{tabular}

\subsection{BDA / ML / AI}

Walt Disney World applied BDA, ML, and AI tools to reduce its electricity use by around 100,000,000 kWh. The company attributed this improvement to the annual collection and sharing of information regarding electricity and other resources at localized levels (Allen, 2005). Similarly, Yedioth, a distributor of newspapers and print magazines, used real-time data on its newspaper sales to pool inventories in its distribution network. Ultimately, BDA tools implemented by Yedioth led to reduced production levels for its magazines and lower levels of product returns (Avrahami et al., 2014). On a similar front, a project called Singapore Live! was launched which promotes "the development of an open platform for the collection, combination, and distribution of large numbers of a city's real-time data, allowing developer communities to join in creating applications that turn these data streams into meaningful and beneficial tools for people to make use of in their cities" (Kloeckl et al., 2012). BDA technologies also improve worker conditions. For instance, LaborVoices used by Walmart allows anonymous workers to generate reports on workplace conditions and practices (de Felice, 2015). On an environmental front, companies are taking steps to reduce the carbon footprint associated with data centers. Big data users like Apple, Google, and Facebook are all striving to use renewable energy for their data centers and operations (Apple, 2017; Google, 2016; Facebook, 2017).

We note that BDA technologies potentially reduce costs and improve worker and environmental conditions, but there are also cases where companies have been victims of cyberattacks. Deloitte and Equifax had privileged and sensitive information compromised in 2017 that affected millions of consumers (Cohen, 2018). Data centers contribute adversely to $\mathrm{CO}_{2}$ emissions, noise pollution, and excessive land and material use. Furthermore, some $\mathrm{ML}$ and $\mathrm{AI}$ algorithms used by companies have been caught up in discrimination controversies. For example, when Amazon rolled out its Same-Day Delivery for Prime members, it used ZIP codes that had the highest concentration of its Prime members so that it could serve more people. Consequently, some neighborhoods populated mainly by African American people did not get included in their service regions. Hence, careful considerations need to be made when implementing these technologies (Ingold \& Soper, 2016).

The process of evaluating BDA implementation cases across sustainability dimensions reveals that BDA can significantly improve economic sustainability for companies by creating efficient solutions that reduce energy costs and inventory levels. Even though this technology can improve social sustainability, but the risks of data breaches and mismanagement of data algorithms are far too high. Companies need to understand the importance of investing in data security and hiring the right talent for algorithm development and data analysis.

\subsection{Blockchain}

Blockchain plays a central role in SSCM through its transparency attributes which ensure sustainable sourcing and consumption of food and other resources. Provenance, in this regard, has used the technology in the seafood industry for transparent and sustainable practices (Steiner \& Baker, 2015). It is estimated that $10 \%$ of food sold is adulterated, which costs the industry $\$ 49$ billion/year worldwide (Grocery Manufacturers Association, 2016). Walmart in collaboration with IBM has been working on improving food supply chains globally with the help of Blockchain. Under a pilot project, the company tracked tens of thousands of sliced mangoes from Mexico to shelves in its retail outlets in the U.S. over thirty days (McKenzie, 2018). Chipotle's stock prices, on the other 
hand, fell by $42 \%$ when an E.coli outbreak from its outlets made customers sick. By using Blockchain to monitor its suppliers in real-time, Chipotle can improve accountability and allow better prevention measures in case of an outbreak (Saberi et al., 2019). Everledger has also used Blockchain to record the entire supply chain of over 2 million diamonds. This includes where the diamonds were mined, cut, and polished to ensure transparency in the process (https://www.everledger.io). Blockchain can prevent forgery attempts and IP spoofing and help certificate authorities like "Google Certificate Transparency" to inhibit counterfeit certificates. A Blockchain platform called Share\&Charge by Innogy SE allows individuals to share their electric vehicle charging stations with others for a profit. Energo in China promotes clean sustainable energy using a similar Blockchain platform. Veridium Laboratories and IBM are using Blockchain to develop carbon-credit market operations. A joint venture by IBM and Maersk is also aimed at securing global trade through Blockchain technology (Forbes, 2018).

However, certain aspects of Blockchain like bitcoin mining consume high levels of energy. There are also some scaling issues whereby pilot projects using Blockchain haven't been scaled to larger extents thus far. Another concern with Blockchain is the garbage-in garbage-out phenomenon. For instance, employees at Kobe fabricated specifications of steel and aluminum company's products that affected more than 500 of its customers like Ford, Boeing, Nissan, and Toyota (McLain, 2017). Unfortunately, Blockchain cannot prevent such fabrication attempts.

Our cross-case analysis shows that Blockchain improves supply chain transparency and reduces costs of intermediation. However, the technology still needs time, investments, regulations, and standardization to move from pilot implementation to mass-scale application.

\subsection{Industry 4.0 / IoT}

Walmart and Carrefour have been using Industry 4.0 tools to make information available on the product's source, environmental characteristics, location, and even its production process through "smart packages" (Kouhizadeh \& Sarkis, 2018). Similarly, Energo uses hardware like smart meters and micro-grid batteries to allow measurement and settlement of clean energy transactions. General Motors (GM) is another excellent case of using Industry 4.0 to optimize performance. The company improved productivity and reduced its energy usage by $40 \%$ and its $\mathrm{CO} 2$ emissions by $41 \%$ over twenty years. One key strategy of GM was to turn off non-essential and energy-demanding machinery when not in use. GM also continues to use sensors to track humidity levels for optimized painting. Workpieces get routed away from parts of the plant that have unfavorable conditions (Cruz, 2015). Boeing, Airbus, General Electric, and Rolls Royce all use data from sensors embedded in their engines for maintenance, monitoring, and personalized services. Similarly, Caterpillar has been using shipboard sensors for its Marine division. One insight gained from their sensor data was that running a large number of generators at low power was more efficient than running a small number of generators at high power. Thus, it can be seen in practice that data acquired from Industry 4.0 technologies can work in harmony with other technologies like Blockchain and BDA to improve the economic, social, and environmental performance of sustainability.

\subsection{P2P/Sharing Economy}

Greenhouse gas emissions, energy and water use, and waste can reduce substantially from Airbnb services. A study by Cleantech Group (2014) suggests that Airbnb guests use 63\% less energy than an average hotel guest and reduce $\mathrm{CO}_{2}$ gas emissions by about $61 \%$ to $81 \%$. Similar claims are made by ride-sharing services such as BlaBlaCar, Mobike, Car2go, and EVCARD. P2P lending platforms, Funding Circle, and RBS Assetz Capital offer expanded choices to customers whose applications for loans do not meet traditional bank's criteria (Ciulli \& Kolk, 2019). iFixit, on the other hand, aims to reduce waste by educating people to repair their gear and providing toolkits and spare parts online. Peerby allows users to lend/borrow items from other users in similar geographical areas. It claims that $85 \%$ of the time, users will find the object they are looking for within 30 minutes (Acquier et al., 2019). Concerning food wastage, an application called "Too Good To Go" allows restaurants and others to sell unsold food at low prices before it gets thrown away. Recupe. Net is another platform that promotes gifting among peers to avoid generating excessive waste. Another interesting implementation of sharing economy is crowdshipping where companies like Zipments, Rideship, FLEXE, and Deliv use neighboring delivery services to fulfill local needs. These platforms lead to benefits like reduced warehousing and vehicle use that jointly benefit environmental and economic performance.

Interestingly, the growth of $\mathrm{P} 2 \mathrm{P}$ in part can be attributed to technological advancements that have reduced transaction costs significantly. However, there are some adverse consequences of sharing platforms that have arisen as well. The safety of users and their assets was compromised in some cases (e.g., Uber, Mobike, OfO, and Airbnb). Airbnb in particular has been criticized for racial discrimination since black hosts have earned less 
rent. Black guests have also been turned down more by the hosts (Gössling \& Hall, 2019). These platforms have also been criticized for tax avoidance and providing unfavorable labor conditions as employees do not get benefits commonly available to full-time employees. Moreover, lack of asset ownership may promote user negligence and lead to a shorter life span of shared assets and higher maintenance costs.

The cross-case analysis indicates that P2P / Sharing Economy reduces waste, energy use, consumption costs, and $\mathrm{Co} 2$ emissions. However, incidents of user security and racial discrimination indicate the need for regulatory intervention. The economic benefits of P2P are vulnerable to shifts in governmental policies that are still being debated and developed.

\subsection{D Printing / $A M$}

General Electric developed an engine component using 3D printing that reduced the weight of its parts by $25 \%$ and attained higher combustion efficiency and reduced $\mathrm{CO}_{2}$ emissions (Ford \& Despeisse, 2016). The technology also enhances the quality of life for people by printing prostheses to combat disabilities and setting up mobile spaces to develop products that tackle immediate necessities in disaster zones (Fieldready.org). A specialized printer can use discarded construction material with cement to print objects. For example, Filabot converts waste into input for 3D printing to support polymer recycling. The cost of construction is lower and minimal human labor is needed (Ford \& Despeisse, 2016). Siemens has also redesigned an integral component of its rotating power machinery which can be repaired through AM (Ford \& Despeisse, 2016). The repair process is ten times faster and produces less waste as the component can be repaired instead of being discarded. Rolls-Royce uses AM to provide repair services locally, faster, and at lower costs. This also leads to lower inventory levels of components and simpler logistics as fewer input materials are needed. Caterpillar uses cold spray AM technology to remanufacture diesel engines. The cost of a remanufactured engine is about $60 \%$ of that of a new engine's price. Caterpillar further extends the product life by replacing products with new and used components before they break. Using AM, General Electric developed a new engine from only a dozen components instead of previously using 855 parts. Fewer components help improve both economic and environmental performance for the company.

Since 3D printing/AM is still in a nascent stage, it faces constraints like an inconsistent stream of inputs free of contaminants. Another issue with using recycled inputs is inconsistency in the quality of materials received. For instance, Fila-Cycle uses recycled materials as inputs and faces production capacity constraints since large extruders used in the process are not available (Despeisse et al., 2017). Even in the case of large firms like Caterpillar, replicating this business strategy to other sectors is a very challenging task.

Overall, 3D manufacturing technology reduces costs for companies and leads to quick response time to disaster relief initiatives. The key challenge that lies here is scalability. Availability and consistency of raw materials is a big barrier and we have yet to see any company apply 3D printing to mass-scale production.

Table 3. Pros \& cons of disruptive technologies on sustainability dimensions

\begin{tabular}{|c|c|c|c|c|c|c|c|}
\hline \multirow[b]{3}{*}{ Technology } & \multicolumn{6}{|c|}{ Sustainability Performance Dimensions } & \multirow[b]{3}{*}{ Case \# } \\
\hline & \multicolumn{2}{|l|}{ Environment } & \multicolumn{2}{|l|}{ Social } & \multicolumn{2}{|l|}{ Economic } & \\
\hline & Pros & Cons & Pros & Cons & Pros & Cons & \\
\hline BDA/ML/AI & $\begin{array}{l}\text { Smart cities, } \\
\text { inventory } \\
\text { pooling, reduced } \\
\text { production } \\
\text { levels, reduced } \\
\text { returns, lower } \\
\text { electricity } \\
\text { consumption, } \\
\text { higher use of } \\
\text { renewable } \\
\text { energy }\end{array}$ & $\begin{array}{l}\text { Noise pollution, } \\
\text { land \& material } \\
\text { use, CO2 } \\
\text { emissions }\end{array}$ & $\begin{array}{l}\text { Improved } \\
\text { worker } \\
\text { conditions }\end{array}$ & $\begin{array}{l}\text { Machine bias, } \\
\text { Cyber-security } \\
\text { attacks }\end{array}$ & $\begin{array}{l}\text { Cost savings, } \\
\text { inventory } \\
\text { pooling, } \\
\text { reduced } \\
\text { production } \\
\text { levels, reduced } \\
\text { returns, higher } \\
\text { revenues, lower } \\
\text { operating costs }\end{array}$ & $\begin{array}{l}\text { Cyber-security } \\
\text { attacks }\end{array}$ & $\begin{array}{l}3,4, \\
11,13, \\
16,21, \\
22,34, \\
38,39, \\
41\end{array}$ \\
\hline Blockchain & $\begin{array}{l}\text { Transparency of } \\
\text { sources, Clean } \\
\text { energy }\end{array}$ & $\begin{array}{l}\text { Higher energy } \\
\text { consumption }\end{array}$ & $\begin{array}{l}\text { Access to less } \\
\text { adulterated } \\
\text { food, product } \\
\text { verification }\end{array}$ & $\begin{array}{l}\text { GIGO adversely } \\
\text { affects } \\
\text { consumers }\end{array}$ & $\begin{array}{l}\text { Substantial } \\
\text { savings, lower } \\
\text { forgery attacks } \\
\text { and IP spoofing, } \\
\text { lower operating } \\
\text { costs, promoted } \\
\text { global trade }\end{array}$ & Scaling issues & $\begin{array}{l}12,14, \\
15,23, \\
26,27, \\
29,38\end{array}$ \\
\hline
\end{tabular}




\begin{tabular}{|c|c|c|c|c|c|c|c|}
\hline Industry 4.0 & $\begin{array}{l}\text { Better access to } \\
\text { cleaner energy, } \\
\text { lower energy } \\
\text { consumption } \\
\text { and CO2 } \\
\text { emissions }\end{array}$ & & $\begin{array}{l}\text { Higher } \\
\text { information } \\
\text { availability to } \\
\text { consumers, } \\
\text { better after-sale } \\
\text { service }\end{array}$ & & $\begin{array}{l}\text { Operational } \\
\text { efficiency, } \\
\text { better } \\
\text { maintenance of } \\
\text { assets }\end{array}$ & & $\begin{array}{l}2,6,8, \\
9,20, \\
21,39\end{array}$ \\
\hline $\begin{array}{l}\text { P2P/Sharing } \\
\text { Economy }\end{array}$ & $\begin{array}{l}\text { Reduced CO2 } \\
\text { emissions, lower } \\
\text { energy \& water } \\
\text { use, lower } \\
\text { waste, lower } \\
\text { food waste }\end{array}$ & $\begin{array}{l}\text { Transportation } \\
\text { density }\end{array}$ & $\begin{array}{l}\text { Small business } \\
\text { loans, customer } \\
\text { support, free } \\
\text { accommodation }\end{array}$ & $\begin{array}{l}\text { Passenger } \\
\text { security, lower } \\
\text { living quality of } \\
\text { residents, racial } \\
\text { discrimination } \\
\text { of users }\end{array}$ & $\begin{array}{l}\text { Fewer setup and } \\
\text { maintenance } \\
\text { costs, lower } \\
\text { transaction } \\
\text { costs, informed } \\
\text { decisions, more } \\
\text { lending than } \\
\text { owning }\end{array}$ & $\begin{array}{l}\text { No sales tax } \\
\text { collection, } \\
\text { shorter life } \\
\text { spans of shared } \\
\text { products, } \\
\text { existing } \\
\text { infrastructure } \\
\text { not suitable }\end{array}$ & $\begin{array}{l}1,5,7, \\
10,19, \\
24,25, \\
28,30, \\
31,35, \\
36\end{array}$ \\
\hline $\begin{array}{l}\text { 3D } \\
\text { Printing/AM }\end{array}$ & $\begin{array}{l}\text { Better } \\
\text { combustion } \\
\text { efficiency, fuel } \\
\text { \& CO2 } \\
\text { emissions } \\
\text { savings, can use } \\
\text { recyclable } \\
\text { materials, } \\
\text { closed-loop SCs, } \\
\text { fewer obsolete } \\
\text { components }\end{array}$ & $\begin{array}{l}\text { Consistent } \\
\text { contamination } \\
\text { free recyclable } \\
\text { inputs is } \\
\text { challenging }\end{array}$ & $\begin{array}{l}\text { Improved } \\
\text { quality of life, } \\
\text { disaster relief, } \\
\text { lower labor } \\
\text { effort, job } \\
\text { creation }\end{array}$ & & $\begin{array}{l}\text { Durable } \\
\text { components, } \\
\text { lower weight } \\
\text { components, } \\
\text { Fosters } \\
\text { innovation, } \\
\text { lower cost, } \\
\text { faster repairs, } \\
\text { simpler } \\
\text { logistics, fewer } \\
\text { components, } \\
\text { increased profit } \\
\text { margins, higher } \\
\text { quality }\end{array}$ & $\begin{array}{l}\text { Sustainable } \\
\text { business models } \\
\text { are challenging, } \\
\text { constrained } \\
\text { production } \\
\text { capacity, } \\
\text { dependence on } \\
\text { supplier } \\
\text { capacity }\end{array}$ & $\begin{array}{l}9,17, \\
18,20, \\
32,33, \\
37,40\end{array}$ \\
\hline
\end{tabular}

\section{Assessment of Implementation Complexity and Sustainability Performance}

Another important aspect to include is the implementation complexity of disruptive technologies, in addition to the impacts of disruptive technologies on sustainability performance, as considered above. The technologies can substantially improve sustainability performance, but adopting and implementing them may be challenging and complex. To obtain a more holistic understanding, we gather information on the implementation complexity of disruptive technology for each case and pair it across its sustainability performance.

A leading roadmap software company that provides collaborative and transparent road-mapping solutions to clients like Nike, Intuit, Alaska Airlines, PBS, and Intuit (Product Plan) proposes using a "Value vs. Complexity" framework. Each initiative is evaluated based on how much value it would bring and how difficult it will be to implement. Initiatives are placed on a quadrant and prioritized accordingly. The dimensions proposed by the company to evaluate complexity are operational cost, time on schedule, training and migration effort, in-house development skills, and risk. Kumar (2011) categorized ERP deployment into six dimensions and evaluated them on their complexity. He used a rating scale that ranged from very low, low, medium, high, and very high ratings.

Delange et al. (2015) evaluated complexity in software models by distributing percentage points based on the effort required. Xia and Lee (2005) also provide a comprehensive list of prior research on information system complexity. They provide three dimensions of complexity; dynamic, organization, and technology. Similarly, we aim to create a matrix that will evaluate the implementation complexity of disruptive technologies against sustainability performance. The dimensions used to evaluate implementation complexity are cost, time, scalability, collaboration, and regulations. Technology that incurs high costs (investment and/or operational), a long time to implement, has limited scalability, requires a lot of collaboration among internal and/or external stakeholders, and has higher regulatory hurdles will be deemed as having high implementation complexity.

We carried out secondary data analysis to supplement existing knowledge of our cases. Our data sources included company websites, annual reports, CSR or Sustainability reports, industry reports, articles, and press releases. Information was collated into a spreadsheet with separate columns for each of the complexity dimensions (cost, time, scalability, collaboration, and regulations) and sustainability performance dimensions (economic, environmental and social). In order to reduce the subjectivity of rating, the three different researchers coded each dimension independently, and inter-rater reliability scores were calculated. For implementation complexity, coders had to choose from a rating scale ranging from 0 to 2 . Here, 0 implied a lack of information for that case and respective dimension. 1 represented "low complexity" and 2 represented "high complexity". 


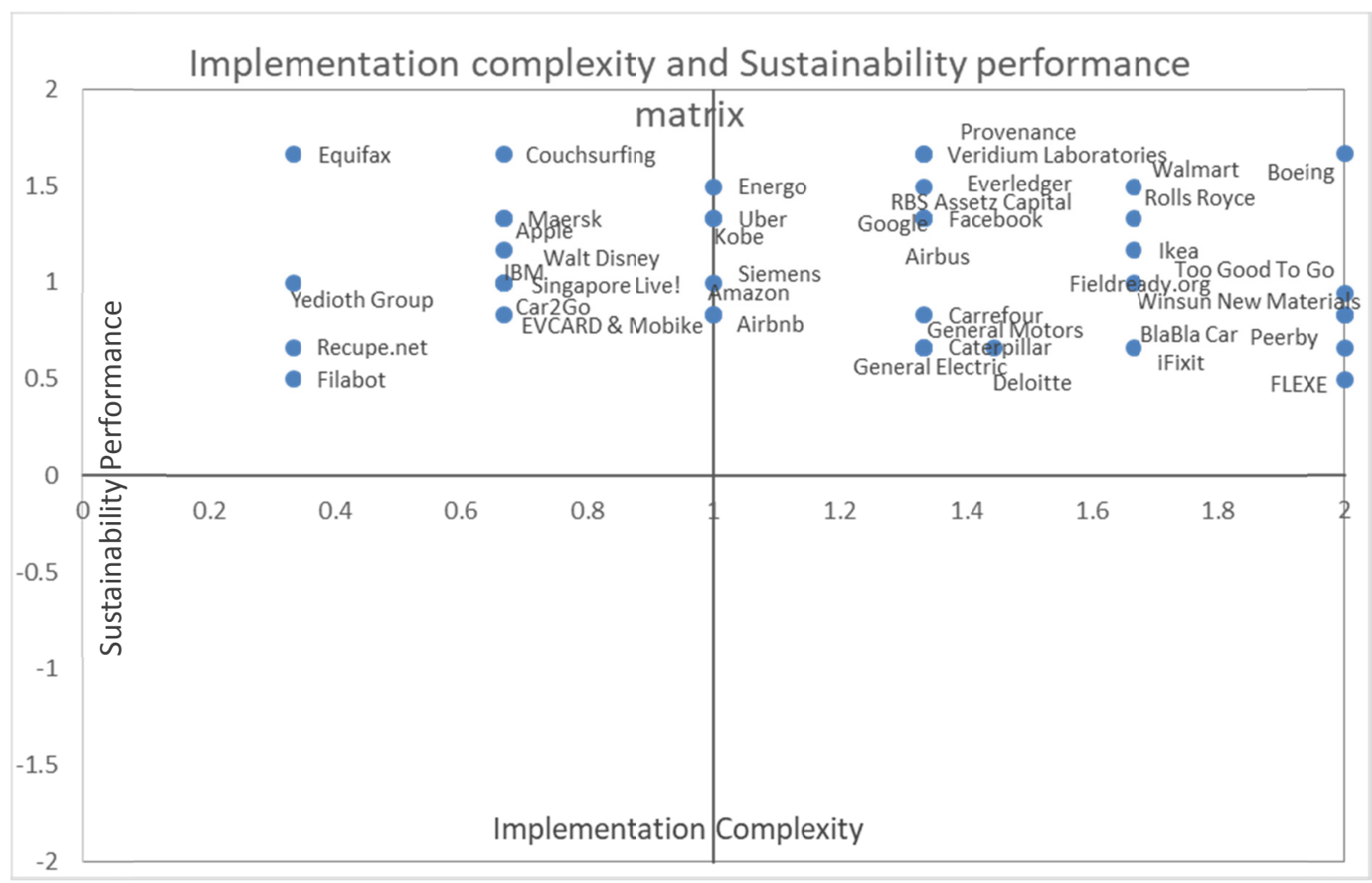

Figure 4. Implementation complexity and sustainability performance matrix

Sustainability performance was evaluated on a scale of -2 to +2 . Here "-2" represented "high negative sustainability impact", "-1" stood for "low negative sustainability impact", "0" signified "lack of information", "1" represented "low positive sustainability impact" and "2" signified "high positive sustainability impact". Three researchers independently coded each case and had inter-rater reliability of $57 \%$ for sustainability performance and $61 \%$ for implementation complexity. The researchers next collaboratively discussed each case where coding did not match, and probed the reasons for differences in assessments until a consensus was reached. For each case, we first took the average of coder rating scores for each sub-dimension. For example, for Airbnb, under sustainability performance, the three researchers on average gave a score of "2" to economic and environmental sub-dimensions, which imply a high positive sustainability impact. The average score for social sustainability performance on the other hand was " 1 " which shows the company has a low, negative impact on social sustainability performance. The average score for sustainability performance for Airbnb was hence the average of its three sub-dimensions i.e., $(2+2-1) / 3=1$. Similarly, an implementation complexity score was determined for each case by taking an average of its sub-dimensions, i.e., cost, time, security, scalability, collaboration, and regulations, and came out to be 0.834 for Airbnb. The company was placed on a four-quadrant matrix with the $\mathrm{x}$-axis representing implementation complexity scores (ranging from 0 to +2 ) and the $y$-axis representing sustainability performance scores (ranging from -2 to +2 ). The results for all 41 cases are shown in Figure 4.

The implementation complexity and sustainability performance matrix show that all our cases have a positive sustainability performance score which indicates that investment in disruptive technologies improves the sustainability performance of firms. Aggregating implementation complexity and sustainability performance scores across types of disruptive technologies show that IoT has the highest sustainability impact followed by the P2P technology. On the other hand, Blockchain has the highest implementation complexity score followed by BDA. Average scores for each technology are shown in Table 4. 
Table 4. Average sustainability and implementation complexity scores

\begin{tabular}{lll}
\hline Technology type & Avg. Sustainability Performance & Avg. Implementation Complexity \\
\hline 3D & 1.333 & 0.857 \\
BDA & 0.949 & 1.182 \\
Blockchain & 1.055 & 1.472 \\
IoT & 1.5 & 1.125 \\
P2P & 1.308 & 0.957 \\
Total & $\mathbf{1 . 1 9 8}$ & $\mathbf{1 . 0 9 2}$ \\
\hline
\end{tabular}

Collectively disruptive technologies have low implementation complexity levels $(\bar{x}=1.092)$ and low positive sustainability impact $(\bar{x}=1.198)$. If we look at individual sub-dimensions for implementation complexity (Table 5 ) and sustainability performance (Table 6), it can be seen that lack of scalability is the highest factor that increases the implementation complexity of disruptive technologies for firms. 3D printing technology faces highest setbacks for scaling businesses. Cost is another big factor that increases complexity for firms and BDA has the highest implementation complexity score in this sub-dimension.

Table 5. Average scores of implementation complexity sub-dimensions across technology types

\begin{tabular}{lllllll}
\hline $\begin{array}{l}\text { Technology } \\
\text { Type }\end{array}$ & $\begin{array}{l}\text { Average } \\
\text { Cost }\end{array}$ & $\begin{array}{l}\text { Average } \\
\text { Time }\end{array}$ & $\begin{array}{l}\text { Average } \\
\text { Security }\end{array}$ & $\begin{array}{l}\text { Average } \\
\text { Scalability }\end{array}$ & $\begin{array}{l}\text { Average } \\
\text { Collaboration }\end{array}$ & $\begin{array}{l}\text { Average } \\
\text { Regulation }\end{array}$ \\
\hline 3D & 1.286 & 1 & 0.286 & 1.857 & 0.286 & 0.429 \\
BDA & 1.727 & 1.273 & 1.455 & 1.091 & 0.818 & 0.727 \\
Blockchain & 1.667 & 0.167 & 1.833 & 2 & 1.833 & 1.333 \\
IoT & 1.5 & 1 & 1.5 & 2 & 0.75 & 0 \\
P2P & 1.23 & 0.538 & 1.385 & 1.308 & 0.436 & 0.846 \\
Total & $\mathbf{1 . 4 6 3}$ & $\mathbf{0 . 8 0 5}$ & $\mathbf{1 . 2 9 3}$ & $\mathbf{1 . 5 1 2}$ & $\mathbf{0 . 7 4 8}$ & $\mathbf{0 . 7 3 2}$ \\
\hline
\end{tabular}

On the upside, economic and environmental factors have a high impact on sustainability performance. Blockchain has the highest economic sustainability impact followed closely by $3 \mathrm{D}$ printing. For environmental sustainability, P2P has the highest impact followed by $3 \mathrm{D}$ printing.

Table 6 . Average scores of sustainability sub-dimensions across technology types

\begin{tabular}{llll}
\hline Technology type & Average Economic & Average Environmental & Average Social \\
\hline 3D & 1.714 & 1.571 & 0.714 \\
BDA & 1.121 & 1.364 & 0.364 \\
Blockchain & 1.833 & 0.5 & 0.833 \\
IoT & 2 & 1.75 & 0.75 \\
P2P & 1.31 & 1.692 & 0.923 \\
Total & $\mathbf{1 . 4 7 2}$ & $\mathbf{1 . 4 1 5}$ & $\mathbf{0 . 7 0 7}$ \\
\hline
\end{tabular}

If we analyze individual cases, the best position in the matrix for a company is to lie in is the top left quadrant. This quadrant represents high sustainability performance and low implementation complexity. FLEXE (P2P) has the lowest implementation complexity score and has a relatively high sustainability impact. Similarly, Fieldready.org (3D), BlaBla Car (P2P), and Too Good To Go (P2P) have the highest sustainability scores with relatively low implementation complexity scores. On the other hand, Equifax (BDA) and Couchsurfing (P2P) have the highest implementation complexity scores with relatively low sustainability performance indicating a higher need for improvement.

\section{Key Findings}

This cross-case analysis of disruptive technologies in SSCM leads to several important findings. First, we find that Industry 4.0 interacts positively with Blockchain (e.g., Energo) and BDA (e.g., Walmart, Carrefour \& Caterpillar) to enhance sustainability performance jointly. Second, we find the impact of each disruptive technology varies in types of technology and sustainability dimensions. For example, our results show that P2P / Sharing Economy and 3D Printing / AM have the highest impact on environmental sustainability. On the other hand, BDA and Blockchain seem to have the worst effect on environmental performance. For the social dimension of sustainability, we find that $\mathrm{P} 2 \mathrm{P}$ has the highest potential to improve social conditions by providing 
employment, rental income, and small business loans. However, P2P also has serious adverse consequences for users due to passenger security, lower living quality of residents, and racial discrimination of users. Third, since these disruptive technologies are at their early stages, many institutional and infrastructure developments still need to be made. In this regard, P2P / Sharing Economy seems to be the most vulnerable to government regulation changes. Government regulations may bring P2P platforms closer to traditional firms concerning tax breaks and employee benefits requirements. Hence the economic advantage currently availed by P2P platforms may cease to exist. Finally, for the long-term sustainability of disruptive technologies, we find that Blockchain and 3D Printing face problems with scaling their projects.

Next, the insights from the cases are utilized to illustrate how disruptive technologies may impact SSCM in the key areas of procurement, design and production, and distribution and reverse logistics.

Procurement. P2P adopted by Peerby allows users to lend or borrow objects from other users in the same geographic area. The platform claims an $85 \%$ chance of finding sought-after objects free of charge within 30 minutes. This changes the procurement patterns of small business owners and individual consumers, improves their economic well-being, and reduces their carbon footprint. On the other end, Fila-Cycle uses the 3D Printing technology to make filaments based on recycled materials. It faces the challenge of obtaining consistent contamination-free 'waste' inputs. Hence, procurement of recyclable content has environmental benefits but also faces supply challenges. Many Blockchain application cases have improved the procurement process. For instance, using Blockchain, Provenance provides transparency in the seafood supply stream and ensures the validity of sustainable activities.

Design and Production. General Electric, Caterpillar, Winsun New Materials, and Rolls-Royce all use 3D Printing to design the products and manufacturing processes so that substantially fewer components are used, repairs get easier, and less human labor is required. Such design mechanisms with the help of 3D printing can reduce costs, generate fewer greenhouse gas emissions, and improve worker conditions. For the social dimension of sustainability, 3D printed prosthetics can improve the quality of life of people with disabilities and tackle immediate necessities in disaster zones more efficiently. On the service end, P2P platforms like Airbnb show that as compared to traditional hotel guest energy consumption, Airbnb users consume about $65 \%$ less energy and have about $75 \%$ lower $\mathrm{CO}_{2}$ emissions. With BDA, Walt Disney was able to reduce both energy and operating costs substantially.

Distribution and Reverse Logistics. Walmart's investment in Blockchain has led to the fast development of smart packages so that a device attached to the package can record information about the package content via Blockchain. Similarly, Maersk in collaboration with IBM streamlines its maritime container operations by ensuring valid and transparent bills of landing via Blockchain. Large-scale implementation of such Blockchain initiatives could save the industry billions of dollars and save time at each stage of its journey. P2P business models like Rideship, Zipmets, and Deliv use available nearby delivery services to fulfill local demand needs. This decreases the need for warehouses and delivery vehicles and improves the economic performance through the consolidation of materials for logistics providers.

\section{Conclusions}

This study has shown that disruptive technologies have significant impacts on SSCM. Even though the benefits of these technologies seem to outweigh their adverse consequences, we should evaluate their long-term implications on SSCM when adopting disruptive technologies. Many cases discussed in this paper reveal that disruptive technologies drastically improve sustainability performance, but also face scalability issues. For instance, for P2P/Sharing Economy technologies like bike-sharing and electric vehicle sharing, infrastructure, and institutional settings are not yet well developed. Developing bike lanes and charging station infrastructure, passing governmental regulations, etc. may require time and resources which need to be taken into consideration. It is also conceivable that the development of infrastructure and its costs to the environment may exceed the environmental benefits. Similarly, Uber and other ride-sharing models currently do not have the same tax laws and labor conditions as the formalized sector. Pressure from activists and the community may also alter some of these costs and benefits and make the P2P/Sharing Economy less economical than envisaged currently. It also raises social issues such as drivers' rights to a share of the benefits. Blockchain and 3D Printing/AM technologies also present similar scaling issues to a large extent. BDA on the other hand faces vulnerability to cyber-attacks and, based on current technologies, has a higher carbon print.

\subsection{Research Contributions}

This study contributes to the SSCM literature by synthesizing three major developments within SCM, namely the adoption of disruptive technologies, the implementation of sustainability practices, and the complexities of 
implementing these technologies. First, no prior research has investigated both theoretical and practical roles of all these disruptive technologies collectively. Second, this research provides a comprehensive review of both positive and negative consequences of disruptive technologies for SSCM. Third, this paper shows how some of these technologies interact with each other synergistically. Lastly, extant empirical research on the relationship between disruptive technology and sustainability performance has mainly focused on individual cases of specific technologies and their impact on SSCM. We conduct a larger, cross-case study and develop a complexity/sustainability matrix that reveals key insights about each case study individually and disruptive technologies collectively.

\subsection{Limitations and Future Research}

One limitation of this study lies in its methodology. Cases were selected as part of a systematic literature review. Other companies which have not been cited in research articles are not part of our cross-case analysis. Some relevant cases have probably been left out due to this methodology. The study is also limited to analyzing the impact of disruptive technologies on the sustainability performance of individual firms. Including the entire supply chain in our analysis would have provided a deeper understanding.

It must also be mentioned that the sustainability triad of social, economic and environmental dimensions is not universally accepted. Environmental activists (e.g., Shiva, 2015) perceive this scheme to be a perpetuation of "neoliberal" policies that ignore the fundamental issues pertaining to climate change. They advocate more radical actions based on a "degrowth" orientation that seeks to reduce society's throughput and improve quality of life (Kallis et al., 2018). Furthermore, understanding the effect of disruptive technologies in the context of developing countries and informal sectors of the economy may lead to different conclusions and should be addressed in future studies. Much of the research work in the past has addressed the concerns of large firms of the developed world and their sustainability impacts. More research is warranted on medium and small firms belonging to the informal sector more widely prevalent in the developing countries. Perhaps more fundamentally, the role of labor and the future of work itself has come to be reexamined, especially since the advent of Covid-19, and these complex issues also need to be investigated in future work. Thus, the social dimension of sustainability needs to include these broader social and psychological impacts of disruptive technologies on supply chain management.

There is also a dire need for empirically testing the impacts of disruptive technologies on SSCM. Traditionally, sustainability and profitability were thought to have a declining curved relationship; investing in sustainability initiatives decreased profitability. Firms would only invest in sustainability to comply with government policies. However, a new revisionist standpoint has emerged and suggests that sustainability can improve profit and the two have an inverted U-shaped relationship. In the long run, the relationship between sustainability and profitability should have an upward angled arrow (Stonebraker et al., 2007). It would be interesting to empirically test how disruptive technologies may moderate the relationship between sustainability initiatives and the triple bottom line (people, planet, profits).

We also suggest the use of organizational theories that can provide insights, and serve to motivate and explain empirical research studies on disruptive technologies in SSCM. First, the institutional theory states that evolving environmental pressures affect firm-level activities (DiMaggio \& Powell, 1983). Based on institutional theory, it would be of interest to verify if mimetic pressures from early adopters of disruptive technologies may influence other organizations to adopt them. Second, the relational view (RV) complements RBV by arguing that firms that combine their resources in unique ways beyond firm boundaries can create competitive advantage (Dyer \& Singh, 1998). Based on RV, it is also important to check if the disruptive technology's impact on sustainability will be different between supply chain firms with strong relational ties and those with weaker ones. Whether relational ties affect the adoption of disruptive technologies and even to the extent they are scaled into projects also needs to be studied. Third, other drivers and antecedents for the disruptive technology's impact on sustainability need to be considered. For instance, under the agency theory, the interests of supply chain members can be better aligned by using disruptive technologies like Blockchain. Fourth, the strategic choice theory stipulates that managerial decisions play a significant role in organizational performance (Child, 1972). It explains how management's support for sustainability and innovation can create a culture that can synergize disruptive technology's impact on sustainability. Finally, other technical drivers like perceived benefits and perceived ease of use, social drivers like attitudes towards innovation and competencies of users, and organizational drivers like leadership (Cresswell \& Shiekh, 2013) influence the adoption of disruptive technologies and should be empirically tested.

The adoption, and ultimately the impact of disruptive technology may be influenced by the technology readiness 
of individuals and firms. Therefore, the magnitude of the impact of disruptive technology may also be influenced by the theory of diffusion of innovations (Rogers, 1995). The theory suggests that fewer individuals/firms will initially invest in disruptive technologies but with improved understanding and persuasion, higher adoption and implementation will take place. There is a need to test the theory of diffusion concerning disruptive technologies as they may have a significant impact at the beginning due to newness and attractiveness but may fade away soon rather than gain momentum due to scalability issues.

It is also important to ascertain that a good fit exists between the task and disruptive technology for it to be sustainable. For instance, Kumar et al. (2019) provide an example of GM and Johnson Controls regarding Blockchain adoption. Their study highlights that since GM has a long-term relationship with Johnson Control, both parties do not perceive the threat of opportunistic behavior to be high. Hence there is little incentive for them to invest in Blockchain technology. Overall, many factors like internal support, coercive pressure, cooperation, technology capability, certified systems, and market pressures are essential for successful disruptive technology adoption (Fu et al. 2018). Hence, a framework needs to be developed and tested considering these factors.

\section{References}

Acquier, A., Carbone, V., \& Massé, D. (2019). How to Create Value(s) in the Sharing Economy: Business Models, Scalability, and Sustainability. Technology Innovation Management Review, 9(2), 5-24. https://doi.org/10.22215/timreview/1215

Agarwal, R., \& Dhar, V. (2014). Editorial—big data, data science, and analytics: The opportunity and challenge for IS research. Information Systems Research, 25(3), 443-448. https://doi.org/10.1287/isre.2014.0546

Ahmad, N., \& Mehmood, R. (2015). Enterprise systems: Are we ready for future sustainable cities. Supply Chain Management: An International Journal, 20(3), 264-283. https://doi.org/10.1108/SCM-11-2014-0370

Ai, C., Han, M., Wang, J., \& Yan, M. (2016). An efficient social event invitation framework based on historical data of smart devices (pp. 229-236). IEEE International Conferences on Social Computing and Networking (SocialCom), IEEE. https://doi.org/10.1109/BDCloud-SocialCom-SustainCom.2016.44

Ali, I., Greifeneder, F., Stamenkovic, J., Neumann, M., \& Notarnicola, C. (2015). Review of machine learning approaches for biomass and soil moisture retrievals from remote sensing data. Remote Sens., 7(12), 16398-16421. https://doi.org/10.3390/rs71215841

Allen, P. (2005). How Disney saves energy and operating costs. HPAC Engineering. Retrieved from http://www.hpac.com/building-controls/how-disney-saves-energy-and-operatingcosts

Anner, N. (n.d.). Additive manufacturing: The power of printing. Retrieved from https://new.siemens.com/global/en/company/stories/energy/additive-manufacturing-turbines.html

Anshari, M., \& Alas, Y. (2015). Smartphones habits, necessities, and big data challenges. The Journal of High Technology Management Research, 26(2), 177-185. https://doi.org/10.1016/j.hitech.2015.09.005

Apple. (2017). Environmental responsibility report. 2017 Progress Report, Covering Fiscal Year 2016. Retrieved from https://images.apple.com/environment/pdf/Apple_Environmental_Responsibility_Report_2017.pdf

Arnold, R., \& Hildebrandt, C. (2017). The socio-economic impact of online platforms. Research brief, June 2017, Wissen schaf tliches Institut for Infrastruktur und Kommunikations dienste, Bad Honnef, Germany.

Aryal, A., Liao, Y., Nattuthurai, P., \& Li, B. (2018). The emerging big data analytics and IoT in supply chain management: a systematic review. Supply Chain Management: An International Journal, 25(2), 141-156. https://doi.org/10.1108/SCM-03-2018-0149

ASTM Standard. (2010). Standard Terminology for Additive Manufacturing Technologies.

Avrahami, A., Herer, Y. T., \& Levi, R. (2014). Matching supply and demand: Delayed two-phase distribution at Yedioth Group-models, algorithms, and information technology. Interfaces, 44(5), 445-460. https://doi.org/10.1287/inte.2014.0759

Babich, V., \& Hilary, G. (2019). Distributed Ledgers and Operations: What Operations Management Researchers Should Know About Blockchain Technology. Manufacturing \& Service Operations Management, https://doi.org/10.2139/ssrn.3131250

Badiezadeh, T., Saen, R. F., \& Samavati, T. (2018). Assessing sustainability of supply chains by double frontier network DEA: A big data approach. Comput. Oper., 98, 284-290. https://doi.org/10.1016/j.cor.2017.06.003 
Barney, J. B. (1991). Firm resources and sustained competitive advantage. Journal of Management, 17, 99-120. https://doi.org/10.1177/014920639101700108

Bauer, W., Hämmerle, M., Schlund, S., \& Vocke, C. (2015). Transforming to a Hyper-connected Society and Economy-Towards an "Industry 4.0". Procedia Manuf., 3, 417-424. https://doi.org/10.1016/j.promfg.2015.07.200

Belk. (2014). You are what you can access: Sharing and collaborative consumption online. Journal of Business Research, 67(8), 1595-1600. https://doi.org/10.1016/j.jbusres.2013.10.001

Benjaafar, S., Bernhard, H., \& Courcoubetis, C. (2017). Drivers, riders and service providers: The impact of the sharing economy on mobility. Working paper, University of Minnesota, Minneapolis, https://doi.org/10.2139/ssrn.3035478

Benjaafar, S., \& Hu, M. (2019). Operations Management in the Age of the Sharing Economy: What Is Old and What Is New? Manufacturing \& Service Operations Management, 22(1), 93-101. https://doi.org/10.1287/msom.2019.0803

Bhandari, S., \& Regina, B. (2014). 3D printing and its applications. Int. J. Comput. Sci. Inf. Technol. Res., 2(2), $378-380$.

Bharadwaj, S., Bharadwaj, A., \& Bendoly, E. (2007). The performance effects of complementarities between information systems, marketing, manufacturing, and supply chain processes. Information Systems Research, 18(4), 437-453. https://doi.org/10.1287/isre.1070.0148

Botsman, R., \& Rogers, R. (2011). What's mine is yours: How collaborative consumption is changing the way we live. London: Collins,

Browne, R. (2017). There were more than 26,000 new blockchain projects last year-Only $8 \%$ are still active. Retrievd February 26, 2018, from http://cnb.cx/2FCWEh3

Burtch, G., Hong, Y., \& Liu, D. (2018). On the Effects of Provision Points in Online Crowdfunding. Journal of Management Information Systems, 35(1), 117-144. https://doi.org/10.1080/07421222.2018.1440764

Buyukozkan, G., \& Berkol, C. (2011). Designing a sustainable supply chain using an integrated analytic network process and goal programming approach in quality function deployment. Exp. Syst. Appl., 38, 13731-13748. https://doi.org/10.1016/j.eswa.2011.04.171

Cachon, G. P., Daniels, K. M., \& Lobel, R. (2017). The role of surge pricing on a service platform with self-scheduling capacity. Manuf. Service Oper. Manage, 19(3), 368-384. https://doi.org/10.1287/msom.2017.0618

Chen, Y.-J., Dai, T., Korpeoglu, C. G., Körpeoğlu, E., Sahin, O., Tang, C. S., \& Xiao, S. (2019). Innovative Online Platforms: Research Opportunities. Manufacturing \& Service Operations Management, https://doi.org/10.2139/ssrn.3098921

Child, J. (1972). Organizational structure, environment, and performance: The role of strategic choice. Sociology, 6, 1-22. https://doi.org/10.1177/003803857200600101

Choi, T.-M., Wallace, S. W., \&Wang, Y. (2018). Big Data Analytics in Operations Management. Production and Operations Management, 27(10), 1868-1883. https://doi.org/10.1111/poms.12838

Christensen, C. M. (1997). The Innovator's Dilemma: When New Technologies Cause Great Firms to Fail. Harvard Business School Press, Boston.

Ciulli, F., \& Kolk, A. (2019). Incumbents and business model innovation for the sharing economy: Implications for sustainability. Journal of Cleaner Production, 214, 995-1010. https://doi.org/10.1016/j.jclepro.2018.12.295

Cleantech Group. (2014). Environmental impacts of home sharing: Phase 1 Report. April 30, 2014. Prepared for Airbnb. San Francisco, CA: Cleantech group.

Corbett, C. J. (2018). How Sustainable Is Big Data? Production and Operations Management, 27(9), 1685-1695. https://doi.org/10.1111/poms.12837

Cresswell, K., \& Sheikh, A. (2013). Organizational issues in the implementation and adoption of health information technology innovations: An interpretative review. International Journal of Medical Informatics, 82(5). https://doi.org/10.1016/j.ijmedinf.2012.10.007

Crosby, M., Pattanayak, P., Verma, S., \& Kalyanaraman, V. (2016). Blockchain Technology: Beyond Bitcoin. 
Applied Innovation Review, 6-9.

Cruz, F. (2015). GM Has Saved \$435 Million in Reduced Energy Costs through 20 Years. Retrieved from http://gmauthority.com/blog/2015/11/gm-has-saved-435-million-inreduced-energy-costs-through-20-years/

de Felice, D. (2015). Business and human rights indicators to measure the corporate responsibility to respect challenges and opportunities. Hum. Rights Q., 37, 511-555. https://doi.org/10.1353/hrq.2015.0031

De Mauro, A., Greco, M., \& Grimaldi, M. (2015). What is big data? A consensual definition and a review of key research topics. AIP Conference Proceedings, 1644(1). https://doi.org/10.1063/1.4907823

Delange, J., McHale, J., Hudak, J., Nichols, W., \& Nam, M. (2015). Evaluating and Mitigating the Impact of Complexity in Software Models. Software Engineering Institute.

Despeisse, M., Baumers, M., Brown, P., Charnley, F., Ford, S., Garmulewicz, A., \& Rowley, J. (2017). Unlocking value for a circular economy through 3D printing: A research agenda. Technological Forecasting and Social Change, 115, 75-84. https://doi.org/10.1016/j.techfore.2016.09.021

DiMaggio, P., \& Powell, W. (1983). The iron cage revisited: institutionalized isomorphism and collective rationality in organizational fields. American Sociological Review, 48, 147-160. https://doi.org/10.2307/2095101

Dolgui, A., \& Ivanov, D. (2020). Exploring supply chain structural dynamics: New disruptive technologies and disruption risks. International Journal of Production Economics, 229(2020), 107886. https://doi.org/10.1016/j.ijpe.2020.107886

Dubey, R., Gunasekaran, A., \&Chakrabarty, A. (2015). World-class sustainable manufacturing: Framework and a performance measurement system. International Journal of Production Research, 53(17), 5207-5223. https://doi.org/10.1080/00207543.2015.1012603

Dyer, J. H., \& Singh, H. (1998). The relational view, cooperative strategy and sources of interorganizational competitive advantage. Academy of Management Review, 23(4), 660-679. https://doi.org/10.5465/amr.1998.1255632

Ekblaw, A., Azaria, A., Halamka, J. D., \& Lippman, A. (2016). A case study for blockchain in healthcare: "MedRec" prototype for electronic health records and medical research data (pp. 1-13). Proceedings of the 2nd International Conference on Open and Big Data. New York, NY: ACM Press.

Elkington, J., Tickell, S., \& Lee, M. (2007). SustainAbility. 20 Years of global leadership [online]. London. SustainAbility. Retrieved from http://www.sustainability.com [Accessed 22 February 2008].

Etzion, D., \& Aragon-Correa, J. A. (2016). Big Data, Management, and Sustainability. Organization \& Environment, 29(2), 147-155. https://doi.org/10.1177/1086026616650437

European Commission. (2002). The world summit on sustainable development. People, planet, prosperity. Luxembourg: Office for Official Publications of the European Communities.

European Parliament Report. (2017). European Parliament Report on a Longer Lifetime for Products: Benefits for Consumers and Companies. Committee on the Internal Market and Consumer Protection. Retrieved August 15, 2019, from http://www.europarl.europa.eu/sides/getDoc.do?pubRef=-//EP//TEXT\%20REPORT\%20A8-2017-0214\%20 0\%20DOC \%20XML\%20V0//EN

Facebook. (2017). Retrieved February 10, 2020, from https://sustainability.fb.com/clean-and-renewable-energy/

Facts and Factors Report. (2020). Industry 4.0 Market Size Growth Will Reach USD 210 Billion by 2026: Facts \& Factors. Retrieved April 25, 2021, from https://www.globenewswire.com/news-release/2020/12/10/2143051/0/en/Industry-4-0-Market-Size-Growth -Will-Reach-USD-210-Billion-by-2026-Facts-Factors.html

Ferrell, O. C., Ferrell, L., \& Huggins, K. (2017). Seismic shifts in the sharing economy: Shaking up marketing channels and supply chains. Journal of Marketing Channels, 24(1-2), 3-12. https://doi.org/10.1080/1046669X.2017.1346973

Forbes.

Retrieved from https://www.forbes.com/sites/rogeraitken/2018/01/16/ibm-forges-global-joint-venture-with-maersk-applyin g-blockchain-to-digitize-global-trade/\#2cfcfd87547e

Ford, S., \& Despeisse, M. (2016). Additive manufacturing and sustainability: An exploratory study of the 
advantages and challenges. J. Clean. Prod, 137, 1573-1587. https://doi.org/10.1016/j.jclepro.2016.04.150

Fu, Y., Kok, R. A., Dankbaar, B., Ligthart, P. E., \& Riel, A. C. V. (2018). Factors affecting sustainable process technology adoption: A systematic literature review. Journal of Cleaner Production, 205, 226-251. https://doi.org/10.1016/j.jclepro.2018.08.268

Gartner Inc. (2007). Gartner Estimates (ICT) Industry Accounts for 2 Percent of Global CO2 Emissions. Retrieved December 9, 2019, from https://www.businesswire.com/news/home/20070426005399/en/Gartner-Estimates-ICT-Industry-Accounts2-Percent

Google. (2016). Enviromental report. Retrieved November 10, 2018, from https://static.googleusercontent.com/media/www.google.com/en//green/pdf/google-2016-environmental-rep ort.pdf

Gössling, S., \& Hall, C. M. (2019). Sharing versus collaborative economy: How to align ICT developments and the SDGs in tourism? Journal of Sustainable Tourism, 27(1), 74-96. https://doi.org/10.1080/09669582.2018.1560455

Grischa B., Niehoff, S., \& Xue, B. (2018). More Sustainability in Industry through Industrial Internet of Things? Appl. Sci., 8, 219. https://doi.org/10.3390/app8020219

Grocery Manufacturers Association. (2016). Retrieved from https://www.prnewswire.com/news-releases/the-grocery-manufacturers-association-gma-and-battelle-launc h-tool-to-fight-food-fraud-300253824.html

Guha, S., \& Kumar, S. (2018). Emergence of Big Data Research in Operations Management, Information Systems, and Healthcare: Past Contributions and Future Roadmap. Production and Operations Management, 27(9), 1724-1735. https://doi.org/10.1111/poms.12833

Guide, V. D. R., \& Wassenhove, L. N. V. (2009). OR FORUM-The Evolution of Closed-Loop Supply Chain Research. Operations Research, 57(1), 10-18. https://doi.org/10.1287/opre.1080.0628

Hahn, G. J., \& Packowski, J. (2015). A perspective on applications of in-memory analytics in supply chain management. Decis. Support Syst., 76, 45-52. https://doi.org/10.1016/j.dss.2015.01.003

Hamari, J., Sj€oklint, M., \& Ukkonen, A. (2016). The sharing economy: why people participate in collaborative consumption. J. Assoc. Inform. Sci. Technol., 67(9), 2047-2059. https://doi.org/10.1002/asi.23552

Han, J., Zhang, D., Cheng, G., Guo, L., \& Ren, J. (2015). Object detection in optical remote sensing images based on weakly supervised learning and high-level feature learning. IEEE Trans. Geosci. Remote Sens., 53(6), 3325-3337. https://doi.org/10.1109/TGRS.2014.2374218

Han, M., Yan, M., Li, J., Ji, S., \& Li, Y. (2013). Generating uncertain networks based on historical network snapshots (pp. 747-758). International Computing and Combinatorics Conference, Springer, Berlin, Heidelberg. https://doi.org/10.1007/978-3-642-38768-5_68

Harrell, E. (2017). Victims of Identity Theft, 2014. U.S. Department of Justice - Office of Justice Programs. Retrieved from https://bjs.ojp.gov/content/pub/pdf/vit14.pdf

Hoehndorf, R., \& Queralt-Rosinach, N. (2017). Data Science and symbolic AI: Synergies, challenges and opportunities. Data Sci., 1, 27-38. https://doi.org/10.3233/DS-170004

Hofmann, E. (2015). Big data and supply chain decisions: the impact of volume, variety and velocity properties on the bullwhip effect. Int. J. Prod. Res., 7543, 1-19. https://doi.org/10.1080/00207543.2015.1061222

Holmström, J., Partanen, J., Tuomi, J., \& Walter, M. (2010). Rapid manufacturing in the spare parts supply chain: Alternative approaches to capacity deployment. J. Manuf. Technol. Manag., 21(6), 687-697. https://doi.org/10.1108/17410381011063996

House of Lords. (2016). Online platforms and the digital single market. Retrieved September 9, 2018, from https://publications.parliament.uk/a/ld201516/ldselect/ldeucom/129/129.pdf

Huang, M.-H., \& Rust, R. T. (2018). Artificial Intelligence in Service. J. Serv. Res., 21, 155-172. https://doi.org/10.1177/1094670517752459

Huang, R., Riddle, M., Graziano, D., Warren, J., \& Das, S. (2016). Energy and emissions saving potential of additive manufacturing: The case of lightweight aircraft components. J. Clean Prod., 135, 1559-1570. https://doi.org/10.1016/j.jclepro.2015.04.109 
Huber, A. (2017). Theorising the dynamics of collaborative consumption practices: A comparison of peer-to-peer accommodation and cohousing. Environ. Innov. Soc. Transit., 23, 53-69. https://doi.org/10.1016/j.eist.2016.12.001

Ingold, D., \& Soper, S. (2016). Amazon doesn't consider the race of its customers. Should it? Bloomberg. Retrieved April 21, from http://www.bloomberg.com/graphics/2016-amazon-same-day

Ji, S., Cai, Z., Han, M., \& Beyah, R. (2015). Whitespace measurement and virtual backbone construction for cognitive radio networks: From the social perspective, in Sensing, Communication, and Networking (SECON, pp. 435-443). 12th Annual IEEE International Conference on, IEEE, 2015. https://doi.org/10.1109/SAHCN.2015.7338344

Jiang, F., Jiang, Y., Zhi, H., Dong, Y., Li, H., Ma, S., ...Wang, Y. (2017). Artificial intelligence in healthcare: Past, present and future. Stroke Vasc Neurol., 2, 230-243. https://doi.org/10.1136/svn-2017-000101

Johnson, H. (2015). Digging up dark data: What puts IBM at the forefront of insight economy. Silicon Angle, Retrieved October 27, 2017, from https://siliconangle.com/blog/2015/10/30/ibm-is-at-theforefront-of-insight-economy-ibminsight/

Kallis, G., Kostakis, V., Lange, S., Muraca, B., Paulson, S., \& Schmelzer, M. (2018). Research On Degrowth. Annual Review of Environment and Resources, 43, 291-316. https://doi.org/10.2307/j.ctv5cg82g

Kaur, H., \& Singh, S. P. (2018). Heuristic modeling for sustainable procurement and logistics in a supply chain using big data. Comput. Oper. Res., 98, 301-321. https://doi.org/10.1016/j.cor.2017.05.008.

Kellens, K., Baumers, M., Gutowski, T. G., Flanagan, W., Lifset, R., \& Duflou, J. R. (2017). Environmental Dimensions of Additive Manufacturing. Journal of Industrial Ecology, 21, S49-S68 https://doi.org/10.1111/jiec.12629

Khajavi, S. H., Partanen, J., \& Holmström, J. (2014). Additive manufacturing in the spare parts supply chain. Comput. Ind., 65(1), 50-63. https://doi.org/10.1016/j.compind.2013.07.008

Khakurel, J., Penzenstadler, B., Porras, J., Knutas, A., \& Zhang, W. (2018). The Rise of Artificial Intelligence under the Lens of Sustainability. Technologies, 6(4), 100. https://doi.org/10.3390/technologies6040100

Kloeckl, K., Senn, O., \& Ratti, C. (2012). Enabling the real-time city: LIVE Singapore! Journal of Urban Technology, 19(10), 89-112. https://doi.org/10.1080/10630732.2012.698068.

Koeleman, E. (2016). Facial recognition of dairy cows. Retrieved from https://www.dairyglobal.net/Articles/General/2016/6/Facial-recognition-of-dairy-cows-2810847W/.

Kouhizadeh, M., \& Sarkis, J. (2018). Blockchain practices, potentials, and perspectives in greening supply chains. Sustainability, 10(10), 3652. https://doi.org/10.3390/su10103652

Kshetri, N. (2018). Blockchain's roles in meeting key supply chain management objectives. International Journal of Information Management, 39, 80-89. https://doi.org/10.1016/j.ijinfomgt.2017.12.005

Kumar, A., Liu, R., \& Shan, Z. (2019). Is Blockchain a Silver Bullet for Supply Chain Management? Technical Challenges and Research Opportunities. Decision Sciences. https://doi.org/10.1111/deci.12396

Kumar, N. (2011). A 'Yardstick' To Simplify ERP Implementation. Manufacturing. Net. Retrieved from https://www.manufacturing.net/home/article/13056281/a-yardstick-to-simplify-erp-implementation

Kumar, S., Mookerjee, V., \& Shubham, A. (2018). Research in Operations Management and Information Systems Interface. Production and Operations Management, 27(11), 1893-1905. https://doi.org/10.1111/poms.12961

Lewis, M. W. (1998). Iterative triangulation: A theory development process using existing case studies. Journal of Operations Management, 16(4), 455-469. https://doi.org/10.1016/S0272-6963(98)00024-2

Li, D., Xu, E. L., \& Li, L. (2018). Industry 4.0: State of the art and future trends. International. Journal of Production Research, 56(8), 2941-2962. https://doi.org/10.1080/00207543.2018.1444806

Linton, J. D., Klassen, R., \& Jayaraman, V. (2007). Sustainable supply chains: An introduction. Journal of Operations Management, 25(6), 1075-1082. https://doi.org/10.1016/j.jom.2007.01.012

Lipson, H., \& Kurman, M. (2010). Factory@home: The emerging economy of personal fabrication. US Office of Science and Technology Policy. Retrieved from http://risti.kaist.ac.kr.gate.lib.buffalo.edu/wp-content/uploads/2013/08/Factory-at-Home-The-Emerging-Eco nomy-of-Personal-Fabrication.pdf 
Lipson, H., \& Kurman, M. (2013). Fabricated: The New World of $3 D$ Printing. Wiley, Chichester.

Lohade, N. (2017). Dubai aims to be a city built on blockchain. The Wall Street Journal. Retrieved April 24, from https://www.wsj.com/articles/dubai-aims-to-be-a-citybuilt-on-blockchain-1493086080

Long, Y., Pan, J., Zhang, Q., \& Hao, Y. (2017). 3D printing technology and its impact on Chinese manufacturing. International Journal of Production Research, 55(5), 1488-1497. https://doi.org/10.1080/00207543.2017.1280196

Manyika, J., Chui, M., Brown, B., Bughin, J., Dobbs, R., Roxburgh, C., \& Byers, A. H. (2011). Big data: The next frontier for innovation, competition, and productivity. McKinsey Global Institute. McKinsey \& Company.

Markley, M. J., \& Davis, L. (2007). Exploring future competitive advantage through sustainable supply chains. International Journal of Physical Distribution Logistics Management, 9(37), 763-774. https://doi.org/10.1108/09600030710840859

Marr, B. (2017). New tool uses machine learning and artificial intelligence to improve IT operations. Forbes. September 26. Retrieved October $4, \quad 2017$ from https://www.forbes.com/sites/bernardmarr/2017/09/26/new-tool-uses-machine-learning-and-artificialintellig ence-to-improve-it-operations/\#648fa05a3789

Merriam Webster. (2018). What Does 'Machine Learning' Mean? (n.d.). Retrieved October 28, 2019, from https://www.merriam-webster.com/words-at-play/what-does-machine-learning-mean

McKenzie, J. (2018). Why blockchain won't fix food safety-yet. Retrieved from https://newfoodeconomy.org/blockchain-food-traceability-walmart-ibm/

McKinsey. (2013). Disruptive technologies: Advances that will transform life, business, and the global economy.

McKinsey. (2015). Manufacturing's next act. McKinsey \& Company Report.

McLain, S. (2017). Mitsubishi materials' quality scandal kept quiet for months. Wall Street Journal (November 24). Retrieved from https://goo.gl/C3Hdsu.

McLellan. (2017). IT Spending and Staffing Benchmarks 2019/2020 - IT Budget. Spending and Staffing Study. Retrieved from https://www.computereconomics.com/page.cfm?name=IT

Meelen, T., \& Frenken, K. (2015). Stop Saying Uber Is Part of the Sharing Economy. Retrieved August 26, 2015 from http://www.fastcoexist.com/3040863/stop-saying-uber-is-part-of-the-sharing-economy

Mišić, V. V., \& Perakis, G. (2019). Data Analytics in Operations Management: A Review. Manufacturing \& Service Operations Management, 22(1), 158-169. https://doi.org/10.1287/msom.2019.0805

Movahedipour, M., Zeng, J., Yang, M., \& Wu, X. (2017). An ISM approach for the barrier analysis in implementing sustainable supply chain management: An empirical study. Management Decision, 55(8), 1824-1850. https://doi.org/10.1108/MD-12-2016-0898

Müller, J. M., \& Voigt, K. (2018). Sustainable Industrial Value Creation in SMEs: A Comparison between Industry 4.0 and Made in China 2025. International Journal of Precision Engineering and Manufacturing-Green Technology, 5(5), 659-670. https://doi.org/10.1007/s40684-018-0056-z

Nakamoto, S. (2008). Bitcoin: A peer-to-peer electronic cash system. Retrieved from https://bitcoin.org/bitcoin.pdf

Olsen, T. L., \& Tomlin, B. (2019). Industry 4.0: Opportunities and challenges for operations management. Manuf. Serv. Operat. Manage forthcoming.

Orcutt, M. (2016). Airplanes are Getting Lighter thanks to 3D-printed Parts. MIT Technology Review. Retrieved April 18 , from https://www.technologyreview.com/s/601268/airplanes-are-getting-lighter-thanks-to-3-d-printed-parts/

Petrovic, V., Gonzalez, J. V. H., Ferrando, O. J., Gordillo, J. D., Puchades, J. R. B., \& Grinan, L. P. (2011). Additive layered manufacturing: Sectors of industrial application shown through case studies. Int. J. Prod. Res., 49(4), 1061-1079. Working paper. University of Auckland. https://doi.org/10.1080/00207540903479786

Piscicelli, L., Cooper, T., \& Fisher, T. (2015). The role of values in collaborative consumption: Insights from a product-service system for lending and borrowing in the UK. J. Clean. Prod., 97, 21-29. https://doi.org/10.1016/j.jclepro.2014.07.032 
Plant, R. (2017). Can blockchain fix what ails electronic medical records? The Wall Street Journal. Retrieved April 27 , from https://blogs.wsj.com/experts/2017/04/27/can-blockchain-fix-what-ails-electronic-medical-records/

Product Plan. (n.d.). Retrieved from https://www.productplan.com/glossary/value-vs-complexity/

Propublica.

(2016).

Retrieved

Sepptember

10

2019 ,

from https://www.propublica.org/article/bias-in-criminal-risk-scores-is-mathematically-inevitable-researchers-say

Rao, P., \& Holt, D. (2005). Do green supply chains lead to competitiveness and economic performance? International Journal of Operations and Production Management, 25(9), 898-916. https://doi.org/10.1108/01443570510613956

Remy, C., \& Huang, E. M. (2015). Addressing the Obsolescence of End-User Devices: Approaches from the Field of Sustainable HCI. In L. Hilty \& B. Aebischer (Eds.), ICT Innovations for Sustainability (p. 310). Advances in Intelligent Systems and Computing, Springer, Cham. https://doi.org/10.1007/978-3-319-09228-7_15

Rogers, E. M. (1995). Diffusion of Innovations (4th ed.). New York: The Free Press,

Rogers, H., Baricz, N., \& Pawar, K. S. (2016). 3D printing services: classification, supply chain implications and research agenda. Int. J. Phys. Distrib. Logist. Manag., 46(10), 886-907. https://doi.org/10.1108/IJPDLM-07-2016-0210

Saberi, S., Kouhizadeh, M., \& Sarkis, J. (2018). Blockchain technology: A panacea or pariah for resources conservation and recycling? Resources, Conservation and Recycling, 130, 80-81. https://doi.org/10.1016/j.resconrec.2017.11.020

Saberi, S., Kouhizadeh, M., Sarkis, J., \& Shen, L. (2019). Blockchain technology and its relationships to sustainable supply chain management. International Journal of Production Research, 57(7), 2117-2135. https://doi.org/10.1080/00207543.2018.1533261

Sasson, A., \& Johnson, J. C. (2015). The 3D printing order: variability, supercenters and supply chain reconfigurations. Int. J. Phys. Distrib. Logist. Manag., 46(1), 82-94. https://doi.org/10.1108/IJPDLM-10-2015-0257

Satyro, W. C., Sacomano, J. B., Contador, J. C., \& Telles, R. (2018). Planned obsolescence or planned resource depletion? A sustainable approach. Journal of Cleaner Production, 195, 744-752. https://doi.org/10.1016/j.jclepro.2018.05.222

Seuring, S., Sarkis, J., Müller, M., \& Rao, P. (2008). Sustainability and supply chain management-An introduction to the special issue. Journal of Cleaner Production, 16(15), 1545-1551. https://doi.org/10.1016/j.jclepro.2008.02.002

Shafri. (2017). Machine learning in hyperspectral and multispectral remote sensing data analysis. Artificial Intel. Sci. Technol., 3-9. https://doi.org/10.1142/9789813206823_0001

Shiva, V. (2015). Earth Democracy: Justice, Sustainability and Peace. North Atlantic Books, Berkeley, CA.

Sood, A., \& Tellis, G. (2013). Demystifying Disruption: On the Hazard of Being Replaced by New Technology. New Theories, 5(1). GfK MIR. https://doi.org/10.2478/gfkmir-2014-0023

Steiner, J., \& Baker, J. (2015). Blockchain: The Solution for Transparency in Product Supply Chains. Retrieved from https://www.provenance.org/ whitepaper

Stock, J., Speh, T., \& Shear, H. (2002). Many happy (product) returns. Harvard Bus. Rev., 80(7), 16-17.

Stonebaker, P., Goldhar, J., \& Nassos, G. (2007). Toward a Framework of Supply Chain Sustainability: The Fragility Index. Production Operations Management Annual Conference, Dallas, Texas.

Sweeny, E., Taschner, A., \& Grünewald, H. (2020). Disruptive digital technology adoption in global supply chains. Journal of Supply Chain Management, Logistics \& Procurement, 3(1), 77-90. https://doi.org/10.1007/978-3-658-28597-5_1

Tan, K. H., Zhan, Y., Ji, G., Ye, F., \& Chang, C. (2015). Harvesting big data to enhance supply chain innovation capabilities: an analytic infrastructure based on deduction graph. Int. J. Prod. Econ., 165, 223-233. https://doi.org/10.1016/j.ijpe.2014.12.034

The Economist. (2010). The data deluge. 
Tien, J. M. (2012). The next industrial revolution: Integrated services and goods. J. Syst. Sci. Syst. Eng., 21, 257-296. https://doi.org/10.1007/s11518-012-5194-1

Tinianow, A. (2018). Directors \& Boards, 42(2), 21.

Tredinnick, L. (2017). Artificial intelligence and professional roles. Bus. Inf. Rev., 34, 37-41. https://doi.org/10.1177/0266382117692621

Truby, J. (2018). Decarbonizing Bitcoin: Law and policy choices for reducing the energy consumption of Blockchain technologies and digital currencies. Energy Research \& Social Science, 44, 399-410. https://doi.org/10.1016/j.erss.2018.06.009

Verma, N., \& Singh, J. (2017). An intelligent approach to Big Data analytics for sustainable retail environment using Apriori-MapReduce framework. Industrial Management \& Data Systems, 117(7), 1503-1520. https://doi.org/10.1108/IMDS-09-2016-0367

Wamba, S. F., \& Akter, S. (2015). Big data analytics for supply chain management: A literature review and research agenda. Lecture Notes in Business Information Processing. Springer International Publishing, Cham. https://doi.org/10.1007/978-3-319-24626-0

Wang, G., Gunasekaran, A., Ngai, E. W., \& Papadopoulos, T. (2016). Big data analytics in logistics and supply chain management: Certain investigations for research and applications. International Journal of Production Economics, 176, 98-110. https://doi.org/10.1016/j.ijpe.2016.03.014

Wirth, N. (2018). Hello marketing, what can artificial intelligence help you with? International Journal of Market Research, 60(5), 435-438. https://doi.org/10.1177/1470785318776841

Xia, W., \& Lee, G. (2005). Complexity of Information Systems Development Projects: Conceptualization and Measurement Development. Journal of Management Information Systems, 22(1), 45-83. https://doi.org/10.1080/07421222.2003.11045831

Xu, L. D., Xu, E. L., \& Li, L. (2018). Industry 4.0: State of the art and future trends. International Journal of Production Research, 56(8), 2941-2962. https://doi.org/10.1080/00207543.2018.1444806

Yannig. (2016). 85\% of the Top 100 Global Brands Use Crowdsourcing-Here's How. eYeka's. Thought Leadership Blog. Retrieved 13, May 2020, from https://news.eyeka.net/2015/07/85of-the-top-100-global-brands-use-crowdsourcing-heres-how/

Zhong, R. Y., Newman, S. T., Huang, G. Q., \& Lan, S. (2016). Big Data for supply chain management in the service and manufacturing sectors: challenges, opportunities, and future perspectives. Computers \& Industrial Engineering, 101, 572-591. https://doi.org/10.1016/j.cie.2016.07.013

Zhou, K., Liu, T., \& Zhou, L. (2015). Industry 4.0: Towards future industrial opportunities and challenges (pp. 2147-2152). 12th International Conference on Fuzzy Systems and Knowledge Discovery (FSKD), Zhangjiajie. https://doi.org/10.1109/FSKD.2015.7382284

Zvezdov, D., \& Hack, S. (2016). Carbon footprinting of large product portfolios. Extending the use of Enterprise Resource Planning systems to carbon information management. Journal of Cleaner Production, 135, 1267-1275. https://doi.org/10.1016/j.jclepro.2016.06.070

\section{Copyrights}

Copyright for this article is retained by the author, with first publication rights granted to the journal.

This is an open-access article distributed under the terms and conditions of the Creative Commons Attribution license (http://creativecommons.org/licenses/by/4.0/). 